Historic, Archive Document

Do not assume content reflects current scientific knowledge, policies, or practices. 


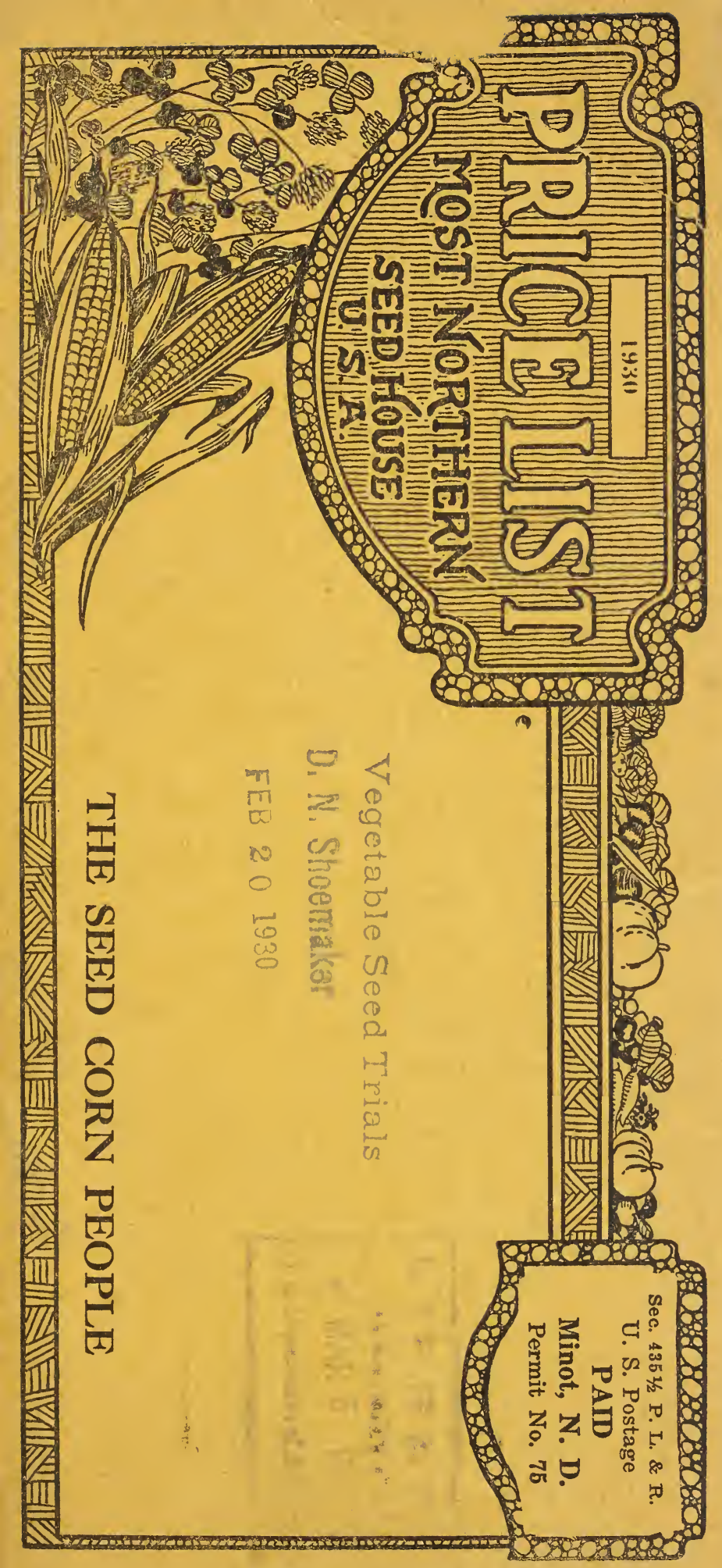




\section{Valker-Christensen Co.}

THE SEED CORN PEOPLE

A complete Seed, Feed and Potato House for farmers of Northwestern North Dakota and Northeastern Montana.

We are pleased to present herewith our 1930 Catalogue and want to thank our growing list of new as well as old customers for the fine support we have been given each year.

We have just completed the biggest and most successful year in our history, thanks to the loyal support of our good customers.

We have added a feed molasses unit to our new elevator, and warehouse, giving us the most modern and complete establishment of the kind in western North Dakota. We pride ourselves in giving better service, more value for the money and enable you to save more freight on your purchases from us, than any other house in the northwest. We are a home owned institution, using local help, purchasing home raised products and supplying a steady, dependable market for farmers in this region.

Special attention to Farmers Union members.

We have dealers in most towns who can supply our seeds. Try them first before writing us.

Farmers Union-Pooling Orders-Wherever farmers clubs or groups of farmers wish to pool seed orders we will quote special prices. Send us a list of your needs for money saving quotations.

Terms of Sale-Cash with order, either in the form of money order, bank draft, or currency by registered mail. U. S. stamps will be accepted on orders of less than $\$ 1.00$. Canadian money accepted without exchange.

Order Early-Supplies of good seeds àre scarce and hard to replace and with markets showing increased tendency to advance we urge early ordering to insure supplies at lowest prices.

Prices Subject to Change-Prices quoted in this list are based on present market conditions and subject to change without notice. We do not change our prices unless absolutely necessary so if your order is not mailed early and you want new prices, same will be gladly furnished upon request.

Delivery-We fill all orders same day as received but in case of delay we will notify you by mail, reason for same and when shipment will go forward.

MOST NORTHERN SEEDHOUSE IN THE UNITED STATES

Save Freight By Buying in Minot 


\section{NO POSTAGE REQUIRED}

Realizing the inconvenience to so many of our customers in securing stamps and having them on hand when ordering seeds and supplies, we have taken advantage of a new postal regulation permitting payment of postage at destination, thus saving our customers bother and making it easier for you to order our merchandise.

We are as near to you as your mail box now. Take advantage of this regulation and order your supplies from us, saving postage, as well as freight and time.

\section{Union National Bank}

Capital $\$ 100,000.00$

Surplus $\$ 25,000.00$

E. S. PERSON, President

C. H. ZEHRINGER, Vice Pres.

H. L. THORNDAL, Cashier

Minot, North Dakota

TO WHOM IT MAY CONCERN :

The Valker-Christensen Company, operating the largest and most modern establishment of its kind in this part of the state, are well and favorably known by this bank and its officers. Starting up immediately after the World War on a very small scale, they have enlarged their business and kept building to meet the increased volume.

They have been customrs of this bank since they began business and we have always found them honest, fair, punctual and aiming at the highest business standards. We believe all orders sent them will receive not only prompt, but careful and conscientious consideration.

Very truly yours,

E. S. PERSON, President.

Send me details of your of fer to accept $25 \%$ of present purchase price and protect me against advancing market, I to pay balance upon arrival of seeds. Use enclosed addressed envelope. No stamps necessary to order from Valker-Christensen Co. 


\section{SEED CORN SITUATION}

Last year North Dakota was proud of its ample stocks and wonderful quality of the seed corn produced. 1928 was a banner year, similar to 1923 when we were able to take in on our contracts some of the best matured and earliest seed corn we have ever sold. Our policy is to carry a two years stock of seed corn for the safety of our trade and as in 1923 we laid in extra stocks of 1928 seed corn, based on past experience of not getting two just as successful years in succession. Because of the volume of seed required, we do not grow all of our seed in one restricted area. This accounts for our being able to offer probably one of the largest stocks of extra fancy, early maturing, North Dakota grown seed corn, that is acclimated, hardy and suited to this region in contrast to the dire shortage reported by so many of our seedhouse friends, who either confined their contracts to single localities or failed to lay in ample supplies of 1928 seed.

Most sections of North Dakota had a complete failure of seed corn, tho they matured the grain, the germination absolutely is not there. Folks will find a wide range of prices in 1930, due to corn looking good, but germination will vary from $30 \%$ up to $99 \%$.

1930 is a year when it will pay the cautious buyer to stick close to shore in buying corn and patronize the dealer and seed house whose past experience and reputation are such that they cannot afford to offer bargains in Minnesota and South Dakota grown corm. Corn is the cheapest seed per acre that is bought. Is it not good insurance to save your pennies on something else and get your corn from Valker-Christensen or one of our dealers? Paying 60c per acre for seed or $45 \mathrm{c}$ per acre may be the difference between success or failure in 1930. Insist on Dakota Leader Seed Corn and your corn troubles are solved. Do not be misled by propaganda by southern and eastern houses with their claims of having as early maturing corn from other states as we have here in North Dakota. It is a reflection on your intelligence and a child should know that the farther north we go, the earlier corn must mature. 


\section{BUY VALKER-CHRISTENSEN CO.- TESTED SEED CORN}

\section{VERIFIED ORIGIN SEED CORN}

When comparing prices bear in mind that you are buying and paying for germination and maturity. Do not confuse our corn of high germination with corn testing 80 per cent or less. Always allow for difference in tests when comparing. Also consider the saving in freight from Minot when comparing.

We are nearest to you and solicit your business as a home concern that gives more value and quality for the money. Some houses are putting out corn at low prices, knowing their germination is low. When you can get from 10 to 20 per cent more germination in our seeds you will agree it is poor economy to buy on price only.

\section{Our Seed Verified Origin by State Agricultural College}

\section{NORTH DAKOTA GROWN}

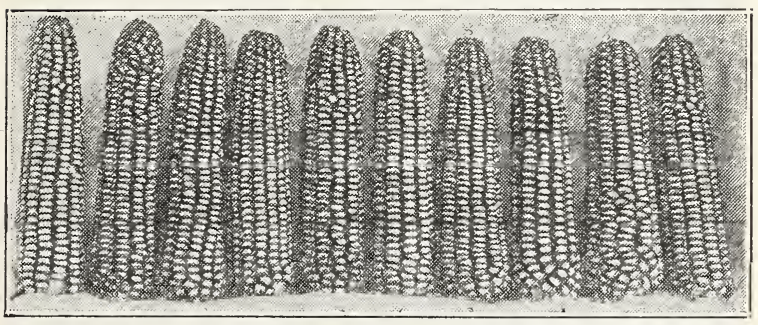

\section{Our Germination $95 \%$}

Northwestern Dent-Most popular dent variety raised in Northwest. Is earliest of dents, year in and yar out. Corn is reddish in color, maturing in about 80 to 90 days. Our corn has been selected for years, breeding for maturity and yield and will outyield the bulk of the so-called Northwestern dents offered. When in doubt order this leader.

Our stock of Northwestern Dent is probably one of the largest in the state. We are holding our price down as long as possible in order to help increase corn acreage in this region. Order now before advances take place.

Per bu. $\$ 4.50$

Seamless sacks extra 40c each 


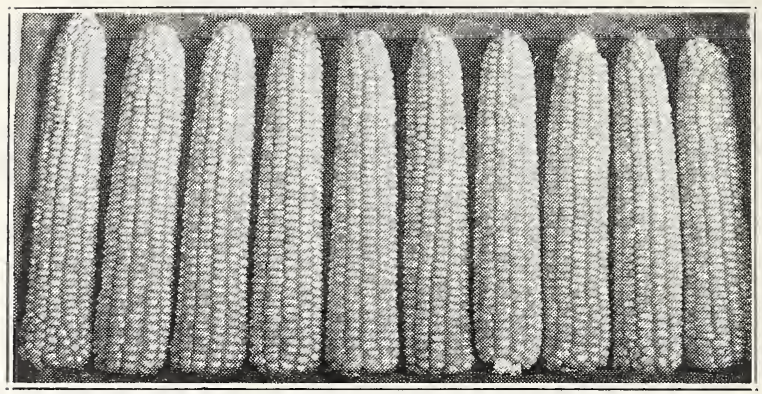

\section{Falconer Corn-Germination $92 \%$}

Falconer Corn-This corn is especially adapted to northern North Dakota and Canada being an early type of corn cross between the dent and flint. Heavy yielding, producing 40 bushels to the acre of ripe corn easily. Ears are large, corn yellowish in color and a small dent appears in the kernels. Consistent in yield and early maturity. Falconer outsells all other varieties except N. W. Dent. Try some this year.

We had one customer along the Canadian line mature as fine a crop of Falconer in 1929 from our seed, as was ever raised. You take no chance with our corn. If it is good enough to mature in a dry year along the border, you are safe in buying it for points south.

Per bu. $\$ 4.50$

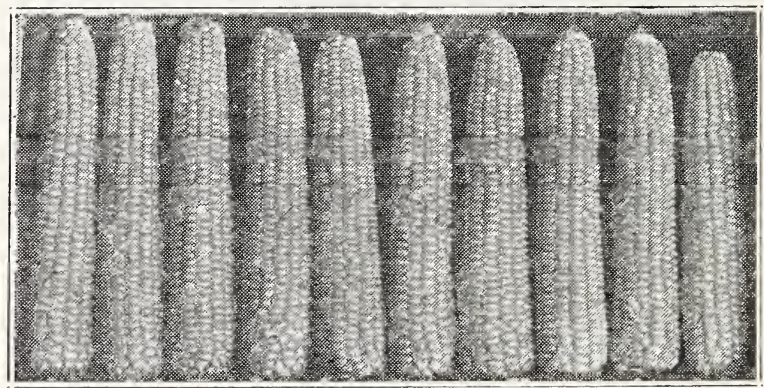

\section{Germination $93 \%$}

Gehu Flint-One of the very early flints, yellow in color. Grows low and yields fairly well. Best suited for hogging off. Has been grown for years in this region and is bred for drouth, hardiness and yield. A sure crop, attaining a height of about four feet under average conditions. Matures from 70 to 75 days.

Per bushel

Seamless sacks extra 40c each 


\section{NORTH DAKOTA GROWN}

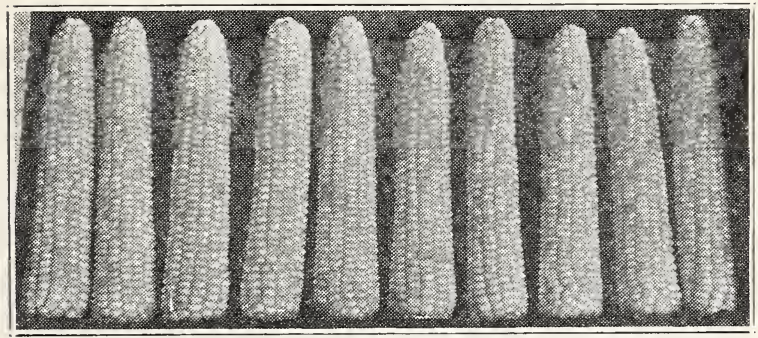

Germination $90 \%$

Dakota White Flint-One of the earliest and an increasingly popular variety for the north. Matures earlier than any of the dents though it will not grow as tall. Ears are lower on the stalk though the yield is very heavy. Cobs are narrow and yield of corn is large. For hardiness, drouth and sure crop. Very good for hogging off.

One of our Plaza friends was in and insisted on getting a supply of the same stock and lot number as he got in 1929. He said it was the best White Flint he ever had. We still have some of the same lot of 1928 seed available.

Per bushel $\$ 4.50$

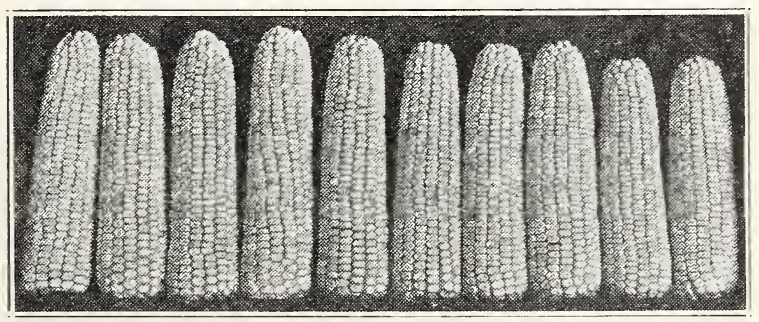

Our Germination $95 \%$

Minn. 13-A medium early yellow dent bred up by the Minnesota station and a popular variety where silage is wanted. Is not as early as Northwestern Dent or White Dent but extremely heavy yielder. Adapted to our condition of soil and climate. Yields high percentage of corn to cob.

Per bushel

Seamless Sacks extra 40c each

$\$ 4.50$

Minot, 1929

\section{Gentlemen:}

Just a word to advise you how well pleased I am with your Minnesota 13 Seed Corn. I planted my corn rather late, but in 3 days it was up and I never had as perfect a stand or as good corn as the Minnesota 13 purchased from you this spring. I certainly recommend your Minnesota 13 for any one wanting corn that yields well and makes real silage. Yours truly,

$$
\text { AL SIMPKINS. }
$$




\section{NORTH DAKOTA GROWN}

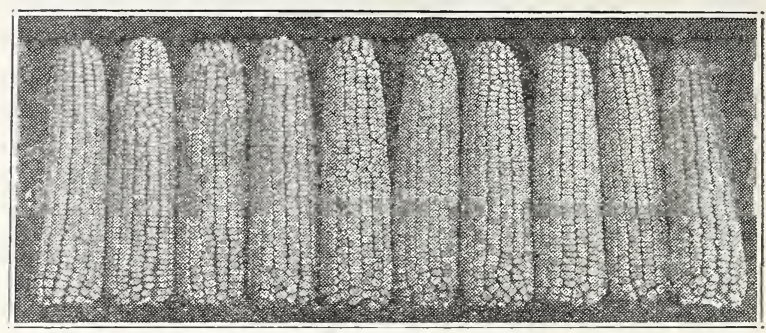

\section{Germination $94 \%$}

Rustler White Dent-Early, sometimes called Pioneer. A heavy yielding early white dent, yielding a volume of nutritious fodder and mature seed corn. Has a very high percentage of shelled corn to cob and is an ideal corn for the farmer who wants an abundance of feed for his livestock to feed either through the silo or for field corn. Matured north of Minot, 1928.

Per bushel $\$ 4.50$

Seamless Sacks extra $40 \mathrm{c}$ each

\section{FODDER CORN-SOUTHERN}

Mammoth Yellow Dent-The most popular fodder corn producing tall stalks with numerous leaves giving an unusually large amount of feed. Can be sown late in the spring and early summer and is coming into more general use each year. Is most generally drilled in at the rate of two or three acres per bushel. Our seed is suitably adapted to the conditions found in this section and where it is getting late and other corn is not in, a few acres of this will furnish a plentiful supply of good feed.

Some dealers are selling South Dakota grown Yellow Dent for Minnesota 13. A comparison of our Yellow Fodder with such Minnesota 13 shows the means adopted by unscrupulous dealers to get a long profit by misrepresentation.

Per bushel

Mammoth White Dent-Similar to the Mammoth Yellow for late seeding where it can be drilked in. Quick grower, heavy producer. Preferred by many farmers over the yellow, although not as universally planted as the Mammoth Yellow Fodder.

Per bushel $\$ 2.25$

Sweet Fodder-Milk cows relish this sweet succulent feed. Will show big gains in feeding. Try a small patch this year.

Per bushel, $45 \mathrm{lbs}$.

Jute sacks extra 20c each 


\section{PURCHASE OF SEEDS MADE EASY}

Many people are holding their grain for higher prices which they feel will come later. However, they will need seed supplies for spring and naturally wish to protect themselves against advances. In order that we may assist you in protecting yourselves on your seed and potato purchases, we will accept your order now, giving you the benefit of present low prices, upon deposit of $25 \%$ of cost of seed, balance to be paid at time of shipment, we to hold such seed at no extra charge.

\section{SUDAN CANE-MISCELLANEOUS FODDER}

Sudan Grass-No forage plant has gained such widespread and popular favor in years as this annual, fast growing succulent feed crop. Grown all over the central west and fast replacing millet as a feed. In favorable years will give at least two or three cuttings. Milk cows show tremendous increase in milk flow when fed this sweet fodder. Fast growing, drouth resistant, heavy yielding sure crop. Attains height of 5 to $9 \mathrm{ft}$. Seed at rate of $15 \mathrm{lbs}$. per acre broadcast or about 5 lbs. per acre in rows 18 to 24 in. apart.

Per 100 pounds

Amber Cane-A sweet succulent feed that dairy cows relish, is unusually adapted to drouth areas, producing several tons of feed annually. Our cane is an early variety which ripens much sooner than the ordinary strains offered in the north. Can be seeded either in rows or broadcast. When sown in rows seed 8 to $12 \mathrm{lbs}$. per acre and when broadcasted about 50 lbs. per acre. Try a few acres this year. Per 100 pounds $\$ 4.90$

Sunflower Seeds-Mammoth Russian-Sunflowers have been growing in popularity for the past few years and many farmers seed considerable acreage for the silo. Should be grown on every farm where poultry is raised, being rich in food elements that increase egg production. Produce very heavy crops and many of our leading farmers highly recommend this crop for silage.

Per 100 pounds

Kaffir Corn-Another drouth resistant corn that thrives in our more rigid regions. Increasing in use each year. Drill in at rate of from 25 to $30 \mathrm{lbs}$. per acre.

Per 100 pounds $\$ 4.90$

We are as close to you as your nearest postoffice. Simply make up your order, check it over and give it to your mailman. No postage needed. We do the rest. 


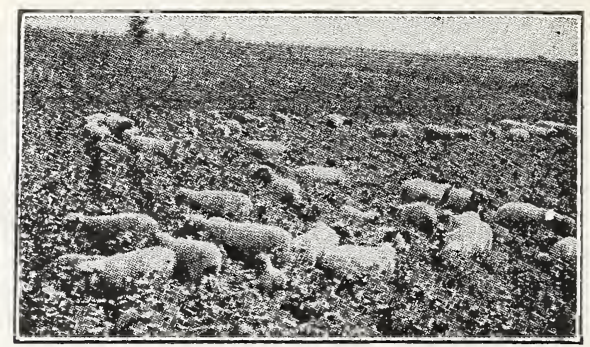

Dwarf Essex Rape-Rape is assuming a more important position each year in the farm where live stock is given consideration. An excellent feed for hogs especially, though sheep and cattle relish it also. Has very high feeding value, being considered even superior to clover in that respect. Seed at the rate of 6 to $10 \mathrm{lbs}$. per acre.

10 lbs. $\$ 1.25$

100 lbs.

Buckwheat-Silver Hull-This wonderful catch crop has been taking like wild fire in many communities, where tried out. Can be seeded late. Matures crop of marketable grain; acts as smother crop for cleaning land; can be sown on light soils. Pays better than wheat. Ideal poultry food.

Per 100 lbs. (sacks extra)

Canadian Field Peas-Are to the North what soy beans are to the South-tremendous soil enricher and high in protein. Early to mature, even better than corn, drouth resistant and not so susceptible to northern climate as other peas. If land needs nitrogen only sweet clover can exceed it in this respect. Fine feed for all kinds of live stock. Can be sown with oats using one bushel per acre.

Per 100 pounds $\$ 6.25$

Jute sacks extra 20c each

Gentlemen:

Brandon, Manitoba, January 4,1930

We are glad to tell you this car has arrived and we have examined and found the Brome equal in quality and purity to the samples by which it was purchased.

If you have any more Brome to offer, we would be glad to hear from you as we might be able to handle a little more.

Yours truly,

A. E. McKENZIE CO. LTD.

We are as close to you as your nearest postoffice. Simply make up your order, check it over and give it to your mailman. No postage needed. We do the rest. 


\section{GRASSES}

Brome Grass-Certified Quack Free. The ac-

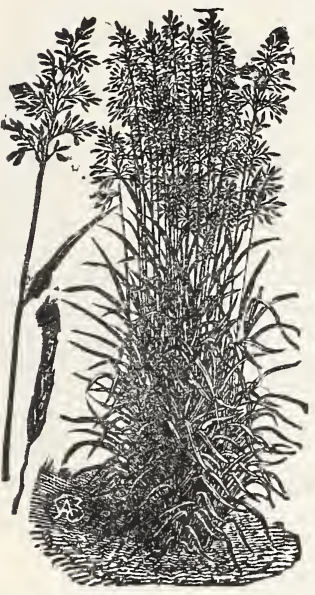
knowledged leader of all grasses in the Northwest. Our seed is absolutely pure and free from quack. No one need hesitate about buying. Suitable for pasture, hay or lawn.

Per 100 lbs. $\$ 18.00$ 100-lb. jute sacks, extra 35c

Western Rye Grass-Sometimes called wheat grass. Makes excellent pasture. Produces heavy yield of hay if cut early. Primarily adapted to prairie soils. Thrives even on alkaline soils. Can be seeded either alone or with brome grass. Quack free seed.

Per 100 lbs. $\$ 12.00$

100 lb. Jute Sacks extra $35 \mathrm{c}$

We are in the heart of the brome raising regions and make a specialty of supplying many other states, as well as Canada with their supplies.

Kentucky Blue Grass-Fancy. Wonderful pasture, withstands cold, starts early in the spring and remains green. Does best on well-drained heavy soils, improves with age. Can be sown with other grasses such as timothy, clover, or brome grass. Best lawn seed known. Crop very short this year. Prices due to advance. Order now.

Per pound $\$ \quad .45$

10 pounds 3.75

100 pounds 29.00

Crested Wheat Grass: Introduced by Bureau of Plant Industry from the steppes region of Russia, adapted to rainfall of less than 20 inches and consequently excellently suited to prairie conditions. Spreads well over the ground and yields some better than brome and slender wheat grass, averaging from 1 to $1 \frac{1}{2}$ tons per acre. Government experts claim every stockman should seed down some for pasture as it gets green earlier than any other grass, is more vigorous, longer lived and heavier producer than brome and rye grass. Seed in early spring without nurse crop, at the rate of 11 lbs. per acre broadcast, or set drill $1 / 2$ the usual rate for wheat per acre if desired to have it in rows. Harvest with binder, when heads turn, preferably on green side. Yields 5 to $40 \mathrm{bu}$. seed per acre. Weighs $23 \mathrm{lbs}$. per bushel.

Per lb.

10 lbs., per lb.

$100 \mathrm{lbs}$. 


\section{TIMOTHY}

Timothy is the most extensively grown grass in the country. Has large bulk of stems, few leaves, and little waste. Starts rapidly, is extremely hardy, excellent for moist, heavy soils. Price is lowest in years.

Per $100 \mathrm{lbs}$.

$\$ 7.75$

Red Top-If you have any low wet places that now are waste land we recommend a mixture of Red Top and Alsike Clover, makes a permanent grass, grows about two feet high and yields abundance of hay. Grows on poor soils where other grasses will lose out. Makes ideal grass on shady lawns.

Per pound

10 pounds

100 pounds

\section{MILLETS}

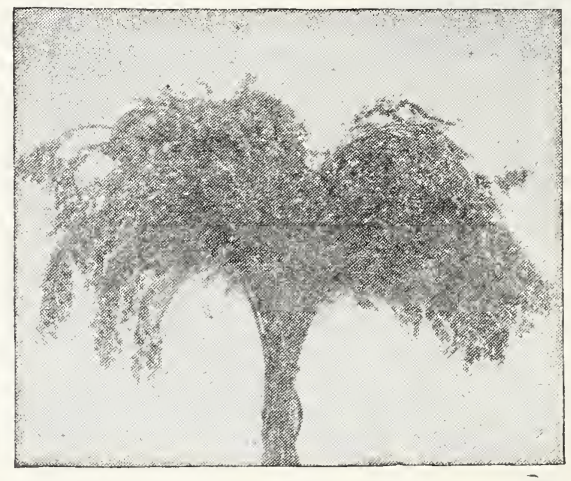

Millet holds a very important place in the Northwest for feed and should be seeded at the rate of 20 to 30 pounds per acre, preferably after the last week in May. Our millet should not be confused with so many cheaper grades that are offered by unscrupulous dealers where a large part of the seed is pigeon grass, which is hard to detect. Buy our best grades of millet and get clean, tested seed that is southern grown.

Siberian Millet, Southern-The premier millet of the Northwest. Very resistant to drouth. Produces heavy crop of hay, fine leaves, tender and nutritious. Seed contains a large proportion of orange colored seeds. Undoubtedly the best producer of hay and seed of any of the millets. Our southern grown seed produces immense tonnage.

Per bushel (50 lbs.) $\$ 2.25$

We are as close to you as your nearest postoffice. Simply make up your order, check it over and give it to your mailman. No postage needed. We do the rest.

Seamless sacks extra 40c, sweet clover, millet, alfalfa 


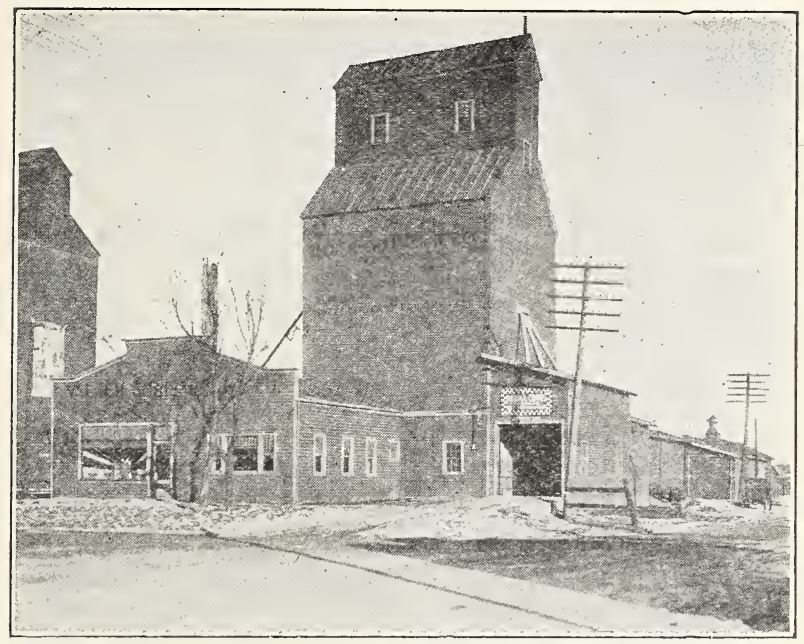

View of our store and cleaning elevator, as well as potato house in rear. This does not show our molasses mixing addition, used in the making of Dakota Leader Feeds. We can load or unload from 6 doors at the same time, handling 3 carloads and 3 trucks without interference.

German Millet, Southern-Sometimes called Golden. Yields an abundance of rich hay varying from four to five tons per acre. Grows taller than home-grown sorts and is more tender in quality. Not as early in maturity as Siberian. Leaves are shorter and broader. Seed is yellowish in color. Very heavy yielder. Price low this year.

Per bushel

White Wonder Millet-Another drouth resistant millet, gaining in favor in the north. Is also a heavy yielder, rapid grower, and extremely early. Seed is whitish in color, a little larger than common or German in size.

Per bushel

Common Millet-An early variety that is adapted to our northern region, producing a large amount

\section{PURCHASE OF SEEDS MADE EASY}

Many people are holding their grain for higher prices which they feel will come later. However, they will need seed supplies for spring and naturally wish to protect themselves against advances. In order that we may assist you in protecting yourselves on your seed and potato purchases, we will accept your order now, giving you the benefit of present low prices, upon deposit of $25 \%$ of cost of seed, balance to be paid at time of shipment, we to hold such seed at no extra charge. 
of hay. Seed is whitish yellow in color and produces more slender stems with little less foliage than German or Golden Millet. More suitably adapted to northern conditions than some millets.

Per bushel

B. C. Hog Millet-An ideal millet to raise for seed, which can be fed to stock profitably, is extremely resistant to drouth, maturing seed with a minimum of moisture. Seed contains more protein and fat than common varieties of millet. Makes good poultry feed.

Per bushel

Early Fortune Millet-Similar to Broom Corn Hog Millet but has reddish seed, and in demand by farmers who want to raise hog millet for early maturity. Will mature where corn cannot and quick grower. Can be seeded late and produces heavily. May be fed to all kinds of livestock. Our stocks are especially fine this year.

This year considerable northern millet was raised and is being offered to the public. We prefer to pay the extra premium to get real southern grown seed.

Per bushel

Seamless sacks extra 40c, sweet clover, millet, alfalfa

\section{SEED GRAINS}

Realizing that there is considerable trading back and forth between neighbors and farmers, we have to do our best to put out a better quality of seed grains than you can get from your neighbors. We have the machinery and equipment for cleaning and grading properly and even though it costs a little more you will be more than compensated in the increased yields that come from planting properly selected and graded seed.

Marquis Wheat-Registered. We have a limited quantity of state registered and certified Marquis grown on potato land in 1929, close to Minot. Seed came from pedigreed Canadian seed in spring of 1229. Protein test shows $17.5 \%$ and color and quality are remarkable. Every effort is being made by all leading agencies to induce the planting of purer and better yielding strains of grains. Buy enough of this Marquis seed, only one generation from Canada, to give you a goodly supply of seed for your entire farm in 1931. $2 \frac{1}{2}$ bu. per bag, sealed and state certified.

Per bu.

$10 \mathrm{bu}$. or more, per bu.

Kubanka Durum-Registered. We have a limited amount of Kubanka durum wheat that was raised from hand picked seed on extremely clean ground. $95 \%$ of the so called seed durum offered for sale contains in excess of 5 to $10 \%$ of admixture of hard spring wheat. Our seed was field inspected and certified by the State Agricultural Colloge. The

Seamless sacks $40 \mathrm{c}$ each extra 
state report shows better than $99 \%$ purity, a remarkable record for durum wheat. North Dakota is short of this variety and we could sell this many times over in one community. However, we want it used as a basis for building up clean pure Kubanka durum seed stocks in this region. If you want a supply of this from hand picked seed, order now. $2 \frac{1}{2}$ bu. per sack. Seamless sacks extra 40c each.

Per bu.

$10 \mathrm{bu}$. lots or more, per bu.

Ceres Wheat-Ceres Wheat is a bearded hard, red spring wheat, introduced by the North Dakota Agricultural College. It is a cross between Marquis and Kota. It has all of the better points of both Kota and the Marquis, being a very heavy yielder having most desirable milling qualities. Like Kota, it is extremely rust resistant and sturdy.

Per bushel

5 bushel lots, per bushel

Spring Rye-Suitable for dry land areas and poor soils. Always produces good crops. Very choice quality.

Per bushel (sacks extra)

$\$ 1.60$

Speltz-This feed has been coming into its own more and more each year. No better feed can be raised for chickens, horses or cattle. Has very high feeding value, thrives in dry land regions especially well, yielding very heavily. If you want to raise for feed, will never have trouble in selling to your neighbors. Our supply the last few years, though large, sold out early. Prices always advance rapidly during spring, so order while stocks are available.

Per bushel, 40 lbs. (sacks extra) _

\section{BARLEY}

Oderbrucker Barley-One of the most popular six-row barley varieties. Tried and tested. Stiff in straw and more resistant to rust than most varieties. Our increasing hog population in the northwest requires the planting of more barley.

Per bushel $90 \mathrm{c}$

Hanchen Barley-This is a two-row barley, good color, raised in Montana, that yielded extremely well. Straw stiff, berry large and plump and fine color.

Per bushel $90 \mathrm{c}$

\section{PURCHASE OF SEEDS MADE EASY}

Many people are holding their grain for higher prices which they feel will come later. However, they will need seed supplies for spring and naturally wish to protect themselves against advances. In order that we may assist you in protecting yourselves on your seed and potato purchases, we will accept your order now, giving you the benefit of present low prices, upon depesit of $25 \%$ of cost of seed, balance to be paid at time of shipment, we to hold such seed at no extra charge.

All prices f. o. b. Minot, drayage free 


\section{OATS}

Growers are learning each year that it pays to seed good clean seed oats. Oats for feed and seed are

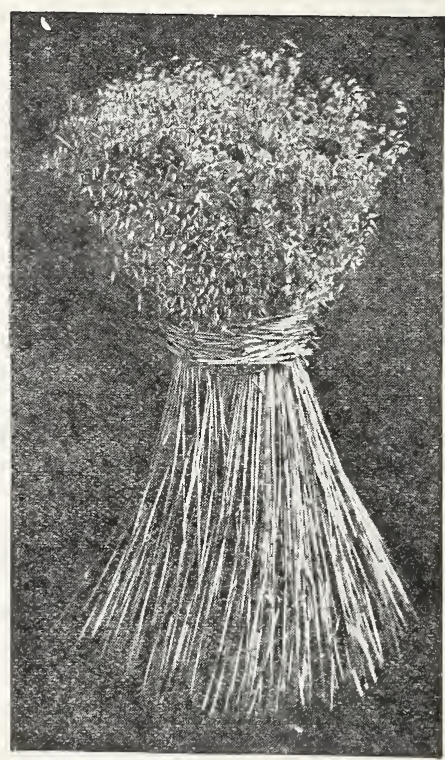

scarce. Those who had good clean oats know from experience that market price is too low and we believe any farmer who puts in plenty of oats this year will profit therefrom. We have now had several good grain years and the cautious farmer will look forward to raising plentiful quantities of f e e d s t u ffs the next few years and use his feed in carrying over and feeding hogs, milk cows and cattle. The best farmers always raise large quantities of feed. We urge every one to hold their feed and not go thru another year, where it becomes necessary to pay fabulous prices for such feed as the stock need.

Use your clean land for oats and corn and you will find it pays big dividends in the form of increased yields of better quality grain.

Swedish Select Oats-One of the most popular varieties grown in the north. Is early, heavy yielding, having stiff straw with spreading panicles. Will not lodge.

Our Swedish Select, though not registered seed is absolutely pure and free of even a trace of wild oats. They really look like they have been hand picked, being so free of impurities. Weigh over 45 lbs. per bu. 1928 crop.

Per bushel (sacks extra) _-_-_-_-_-_______-_95c

10 bushels, per bushel $85 \mathrm{c}$

60-Day Oats-Has not as large berry as Swedish Select but very heavy yielding, extremely early maturing. Does not lodge. Earliness predominating advantage of these oats.

Per bushel (sacks extra) _..-_-_-_-_-_-_-_90 10 bushels, per bushel 
Gopher Oats-Registered. So much has been written about different varieties of oats with false claims as to yield, quality, meat content, etc., that it is gratifying to be able to offer this variety which is standing up and making every other kind of oat look mediocre. Gopher oats take a back seat to none. The seed we have to offer was grown on a pedigree seed farm where weeds are never tolerated. Our grower, in buying his seed stocks cares not whether his own seed costs ten times the market price, because clean, graded and well bred seed outyields the other and pays big dividends. Imagine getting oats that yielded over $70 \mathrm{bu}$. in dry 1929 and so free of impurities that they look like hand picked seed.

Pick out a clean piece of land and get started this year to increase and build up your oat supply. We have never had such quality to offer in oats; heavy, pure, outstanding yield, state certified and priced low. Order now. 3 bu. per sack.

Per bu. $\$ 1.00$

Seamless sacks extra $40 \mathrm{c}$ each.

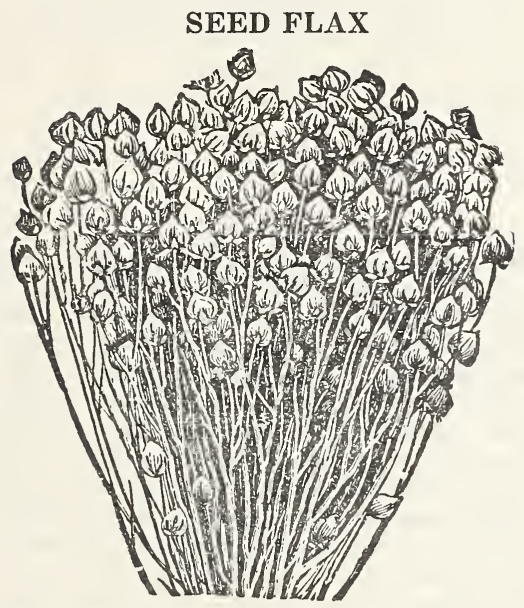

We have made some comparisons on our seed flax as to value of grading. Where the elevator dockage on our incoming seed stocks may show 2 or $3 \%$ we generally grade out up to $10 \%$ of the light weight berries, thus giving the buyer healthier, bigger yielding stocks. This costs us extra money but results in the buyer getting 2 to $3 \mathrm{bu}$. more yield per acre over planting the same seed cleaned on the average farm mill, leaving such light weight berries in.

Our Mr. Christensen spent many years with the State College and government on flax work and pure seed work, which accounts for his appreciation of the grower's viewpoint in wanting to get the best available seed stocks properly cleaned. 
Bison Flax-Registered-One of the latest varieties given North Dakota farmers by our state experiment station. Heavy yielding, good straw. This flax sure prize winner at all grain shows. Our stocks raised on clean land, inspected by Pure Seed Commissioner's office and seed cleaned and registered in sealed bags under state supervision. Limited suppiy. Order early. $2 \frac{1}{2} \mathrm{bu}$. to each sack.

Per bu.

$10 \mathrm{bu}$. lots or more, per bu. $\$ 4.85$

Linota Flax-Wilt resistant, heavy yielder, and in keen demand by those who have tried it. Growers tell us they get many bushels per acre more than from other kinds. Has been grown long enough to be known as one of the best varieties available.

Per bushel

N. D. R. 119 Flax or Buda-Registered-The most recent addition to the wilt resistant family from the Agricultural College. This flax has been out a few years so that stocks are limited. Growers claim phenomenal results and fine yields from this flax. Our stocks are small but fine quality.

Per bushel (sacks extra)

N. D. R. 114 Flax-Best wilt resistant strain known, combining heavy yield, long straw with high resistance to wilt. Where flax has been grown before, play safe by seeding this sure money-making crop. This seed yielded heavily on clean land for the last four years.

Per bushel

\section{ALFALFA}

Alfalfa acreage has been increasing tremendously compared to what it did a few years ago. Western North Dakota and eastern Montana with their alkaline impregnated soils are ideal for growing this wonderful legume. Another ten years will see ten times the alfalfa grown that there is now. Seed has to be planted only once so that regardless of cost per pound, its cost per acre is low. One ton of alfalfa hay is equal to one ton of bran in feeding value. With dairy cows, poultry, hogs and live stock playing such an important part in increasing farm income, legumes such as alfalfa must be planted on every farm if live stock is to pay better. All farm grains such as oats and barley are low in protein. When fed to dairy cows they will produce only a fraction of what they are capable of. Alfalfa hay will do more towards increasing milk production and decreasing cost of production than any other factor.

Alfalfa is a sure crop. Consult your County Agent or A. C. representative, or write us for our alfalfa booklet. Decide now to put in some alfalfa for hog pasture and a field for hay. Raise both alfalfa and sweet clover.

We are as close to you as your nearest postoffice. Simply make up your order, check it over and give it to your mailman. No postage needed. We do the rest. 


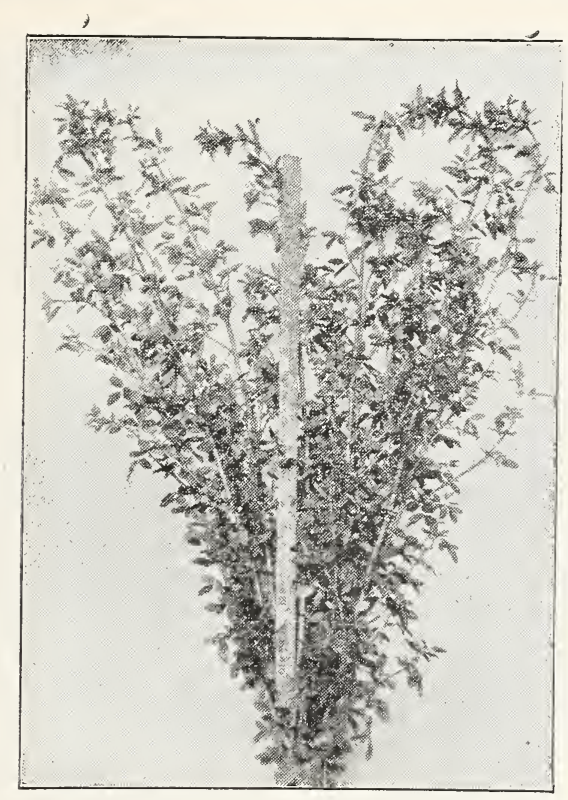

Seed crop this year in some parts of the state are greater than for many years and prices lower. We believe it an opportune time to seed down a field, even if only 5 acres. To those who already have a small patch and want to increase their acreage, we offer seed of unquestioned origin, hardy, acclimated and at prices that are considerably under those of previous years.

We urge the seeding of registered seed if you are going into seed production. For hay and pasture the unregistered home grown seed is just as good as $95 \%$ of North Dakota alfalfa is really Grimm, tracing back to A. B. Lyman of Excelsior, Minn. Most growers have not kept up their registration papers but this does not affect the hardiness or quality.

Alfalfa, Grimm-Registered-Blossoms are variegated in color. Is the most hardy of the commonly grown varieties in North Dakota. Seed not less than 8 lbs. per acre, shallow on MiITRACIN firm, clean seed bed. Our registered Grimm alfalfa is officially sealed by state commissioner. We have kept each grower's lot separate and have record of original identity and which field seed is from. Our seed is western North Dakota grown. Stocks are scarce this year, so order early.

Our red tag registered seed is so high in quality and purity that it surpasses some and is equal to most blue tag, but for some trivial matter such as color of seed. We urge the seeding of Red Tag Number One seed for seed production. Put up in 
$30 \mathrm{lb}$, $60 \mathrm{lb}$., and $100 \mathrm{lb}$. and $150 \mathrm{lb}$. sacks. State sealed and Certified. Seamless $40 \mathrm{c}$ each.

$100 \mathrm{lbs}$. $\$ 39.00$

$50 \mathrm{lbs}$. 24.00

30 lbs. 12.60

Grimm Alfalfa-Discolored. We have a limited quantity of genuine Grimm that has a small percentage of discolored seed. It may not look as good as the top grade seed but we are discounting the price due to color. Order early, stock limited.

50 lbs. $\$ 15.00$

100 lbs. 29.00

Affidavit Grimm-Extra Fancy-Practically all of the alfalfa grown in North Dakota or Montana originally came from A. B. Lyman and is undoubtedly genuine Grimm alfalfa. The fact that it has withstood the rigorous winters for the last 15 years indicates that it is Grimm. Most people who raise alfalfa seed either through carelessness or neglect do not keep up the registration of field. Seed, therefore, is not officially registered seed. Our seed is all North Dakota grown from reliable parties from whom we have secured affidavit showing origin of seed. Seed is put up in sealed bags.

$50 \mathrm{lb}$. bag

100 lb. bag

Cossack Alfalfa-While comparatively little is known of this wonderful variety that was brought to this country from Siberia by Prof. Hanson of the South Dakota Experiment Station, we find that those who have tried it believe it is destined to outrank the Grimm in popularity. It yields more hay per acre having more leaves per plant, has more root system and questionnaires to those growers having had experience with both varieties, we find that they prefer the Cossack. Put up in sealed bags.

50 pounds $\$ 21.00$

100 pounds 40.00

Registered Seed, state sealed, $100 \mathrm{lbs}$. - _-_-_ 44.00 Registered Seed, state sealed, 50 lbs. ______ 23.00 N. D. Alfalfa-Hardy, acclimated seed. Dry land grown.

Per 100 pounds $\$ 26.00$

Montana Alfalfa-Dry land grown, scarified, hardy, vigorous, acclimated seed.

Per 100 pounds $\$ 26.00$

Seamless sacks extra 40c, sweet clover, millet, alfalfa

\section{Gentlemen:}

Lansford, N. Dak. Dec. 6, 1929.

The 300 chicks we purchased from you were certainly the healthiest and liveliest lot of chickens we ever had. We cannot recommend too strongly the quality of the chicks you sell. We have been getting a big bunch of eggs from the pullets which pleases us immensely, as most of our neighbors are not getting eggs and had earlier chicks than ours. Your chicks and Dakota Leader Poultry Feeds are good enough for us.

\section{Yours truly,}

Mrs. Ernest Heath. 


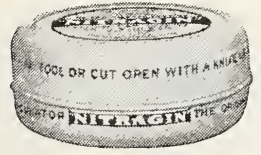

\section{INOCULATE}

Use the original inoculant for alfalfa and sweet clover. Makes failure impossible. The most bacteria per dollar of any sold.

30 lb. seed uses pkg. $\$ .60$

$60 \mathrm{lb}$. seed uses pkg.

$300 \mathrm{lb}$. seed uses pkg.

Garden size for sweet peas, beans and peas -1.20

\section{SWEET CLOVER}

North Dakota has made more progress the last five years than in the previous ten years along diversification lines, in building up soil fertility, providing feed for live stock and reducing the weed hazard. It is destined to make twice as much progress in the next five years. Probably the greatest factor contributing to this development has been the growing of sweet clover. Sweet clover is just coming into its own. It takes years to break down the prejudice of our older farmers from southern states, who always considered sweet clover a detrimental weed. Our leading authorities as well as foremost farmers now rank sweet clover with alfalfa as a feed and pasture crop. Sweet clover has this advantage, being a biennial or two-year crop, it can be plowed under as a green manure, thus insuring tremendous increase in succeeding crops of grain.

Nitrogen has to be bought in the southern states in the form of fertilizer. The northwest can furnish nitrogen cheaper thorugh the planting of sweet clover. Southern and eastern states have taken hold of sweet clover by leaps and bounds since the war and have substituted sweet clover as a green manure in the place of red clover, which has been prohibitive in price. North Dakota is the largest seed producing state in the union and where properly handled, sweet clover seed production is extremely profitable.

Due to stock market collapse in the east which has caused a money stringency, many of the eastern seed houses, who have been carlot buyers in the fall and winter have been unable to borrow money to

\section{NO POSTAGE REQUIRED}

Realizing the inconvenience to so many of our customers in securing stamps and having them on hand when ordering seeds and supplies, we have taken advantage of a new postal regulation permitting payment of postage at destination, thus saving our customers bother and making it easier for you to order our merchandise.

We are as near to you as your mail box now. Take advantage of this regulation and order your supplies from us, saving postage, as well as freight and time. 


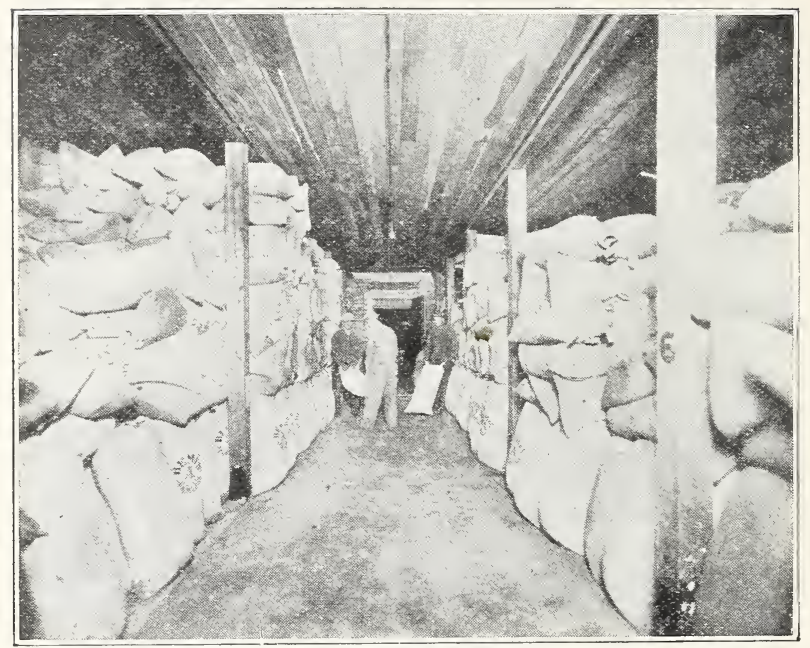

One of our seed storage rooms, showing one of the tiers of recleaned seed sacked and ready to go out. In addition to this full building, we have another warehouse filled with over $1,000,000 \mathrm{lbs}$. of seed to take care of western N. D. and eastern Montana customers.

carry their stocks as in former years. This has made it appear that the market for sweet clover in the east has been declining, which is not true. At time of going to press we now find an increasing demand from the east and feel confident that every pound of available sweet clover seed in hands of growers or dealers will be disposed of and at advances over the present quotations. We urgently recommend the buying of large supplies at present low levels and seed down 1-3 of your land at these money saving quotations, thus taking advantage of the money situation created by the stock market collapse and turning it for good for yourself.

Our seed is not Red River Valley seed so there need be no fear of getting sow thistle, quack and other noxious weeds when purchasing from us. We never blend cheaper grades with higher grades to enable us to quote "bargain seed", which generally turns out to be expensive seed.

We specialize on sweet clover and ship all over the United States. Seed houses pay us a premium for our seed knowing it is far superior in quality and color to Red River Valley and Minnesota seed.

Every farmer who wants high protein wheat should seed down at least one-third of his farm yearly to sweet clover. It is now a common practice for mortgage companies who have thousands of acres of land to get in shape for selling to seed down a fixed acreage of sweet clover annually. In a few years their land is all cleaned up and commands a premium when ready to be sold. 
We have heavy stocks of seed of various qualities to suit every purse. If you want to seed down a large acreage to be used for plowing under, you will find our choice and second grade good enough and it will save you money.

White Sweet Clover-Mammoth. Most commonly used. Contains large root system. Roots decay rapidly, putting much humus in soil and break up sub-soil, enabling rains to

INOCULATE THIS SEED

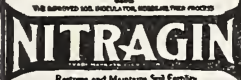
penetrate and store up water. Seed at rate of 15 pounds per acre for best results. Do not try to take crop of hay and seed same year, if seed crop is wanted. If spring is very wet, advise clipping high with binder about middle of June. Cut for seed when crop half ripe. If cut for hay, will get best quality at blossoming time.

Extra Fancy Quality-Bright golden color 99.8 per cent purity.

Per 100 pounds $\$ 8.50$

Fancy Quality-99 per cent purity.

Per 100 pounds $\$ 8.00$

Choice Grade-Contains sprinkling of cracked rye and some greenish seed, having been cut a little on the green side. Germination high. Possibly not as good to look at from the show standpoint. Absolutely satisfactory to use for plowing under or for pasture purposes.

Per 100 pounds

2nd Grade-This is small seed that has been graded out of our fancy quality. Germination and purity good, contains no foul or noxious weed seeds and is much better seed than you will buy from your neighbors, where you get weeds and unhulled seed. All our sweet clover scarified and recleaned, meeting with rigid state seed law requirements.

Per 100 pounds

Grundy County or Dwarf Sweet Clover-This variety matures earlier than common white, has white blossoms. Has somewhat the same growing characteristics as the yellow. Is best suited for heavy soils where rank growth of the common white makes more difficult handling. We recommend this variety for heavy soils and on gumbo.

Per 100 pounds $\$ 8.00$

Sweet Clover, Yellow Blossom-This variety grows shorter and hugs the ground more. Makes a better permanent pasture than white blossom. Is harder to kill out. Blossoms about 10 days earlier than white blossom and when mixed with the white will eventually displace the white blossom. Has never been grown as extensiveINOCULATE THIS SEEO

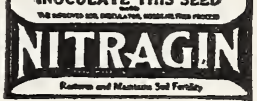
ly in North Dakota as in Montana. Is more tender for hay and pasture and does not have as extensive 
root system in breaking up sub-soil and does not put as much humus back into soil, due to smaller size plants.

Yellow blossom is very short crop and hard to get. While stocks of white are plentiful now, shortage of yellow is already acute. We suggest buying Grundy County or Dwarf if unable to secure enough yellow or you want to buy seed at less money.

Extra Fancy Quality-Scarified.

Per 100 pounds $\$ 10.25$

Fancy Quality-

Per 100 pounds

Alsike Clover-This clover does best on moist or low land where it is hard to get on in the spring due to standing water. Should be sown with Red Top and timothy, when excellent hay can be secured.

Per 100 pounds $\$ 24.75$

White Dutch or Lawn Clover-Finest quality clover for lawns; low growing, very fragrant. Does well on moist soils.

Per pound

5 pounds

\section{BEE SUPPLIES}

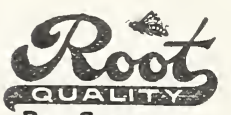

BeE SUPPLIES

We are agents for the A. I. Root Quality Bee Supplies. If interested in hives, starters for brood frames, supers, 1-lb. boxes, wood separators, covers, wires, brushes, frames, queen excluders, cartons, books, signs, and all other Bee Supplies, write for our special catalogue, which will be sent free upon request.

\section{BINDER TWINE}

We are northwestern distributors for some of the leading grades of binder twine, which enables us to quote you on your requirements at rock bottom prices. Keep us in mind when in the market and write us for money saving quotations. Special prices to car-lot buyers.

\section{GOPHER POISON}

We are the largest mixers of government formula, super strength gopher poison in the northwest, supplying a large number of townships and counties with their poison.

8-1b. sack $\$ 1.25$

16-lb. sack

32-lb. sack 4.00

All prices f. o. b. Minot, drayage free

Gentlemen:

Melville, Mont. January 1930

We bought 300 chicks from you last season and were very well pleased with them. They developed into a fine flock, and part of the pullets have been laying all winter.

Very truly yours, C. A. Rupert. 

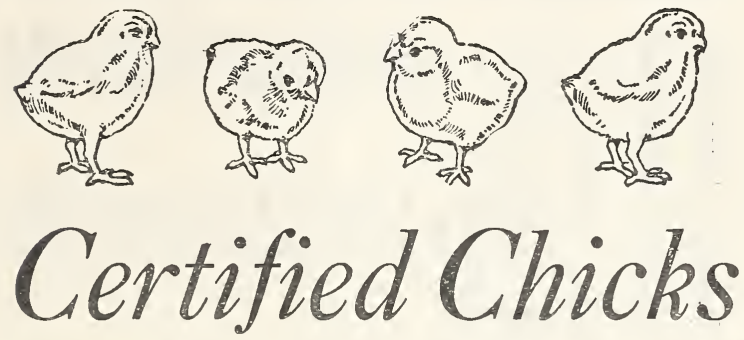

\section{Gentlemen:}

We secured 300 Leghorns last season from you and raised better than $95 \%$ of them. They are healthy and big and are laying lots of eggs, even tho our facilities are not the best for laying hens. We are certainly well pleased with the high quality chicks you sell.

Frank Marsland.

\section{Per Cent Live Delivery Guaranteed}

We mean just that! 100 percent live, and full delivery guaranteed-or we will promptly and cheerfully refund your money. Our Baby Chicks are bred from such high class, pedigreed stock, are so sturdy, strong and healthy (although only a day old), that we know for sure they will reach you in $A$ No. 1 shape. We even include one extra chick for each 25 ordered, doubly insuring 100 per cent live delivery. They are all one size and age. No order too small or large. 25 or 2500 , in one order receive the same careful attention from us. Satisfied customers is our watchword. All charges prepaid. Order early.

\section{FANCY STANDARD BRED-TO-LAY CHICKS}

When you order baby chicks from us, you are not going to get chicks that were hatched from eggs bought at the lowest price. Our Chicks are all from parent stock that has been carefully culled, rogued and mated. They have been bred for high egg production, and not infrequently, show birds are found amongst them. They are strong, healthy, hardy, acclimated, free from disease and just the thing for the good all around poultry flock.

NOTE: Our prices are for delivery of Baby Chicks during March, April and May. If you order Baby Chicks for delivery any time from May 15 to June 15, figure 1c each less; after June 15, figure $2 c$ each less.

\section{Gentlemen:}

I received the 25 Buff Orpington Baby

Chicks. They came through fine.

Yours very truly, Mervin Peterson, Big Sandy, Mont. 


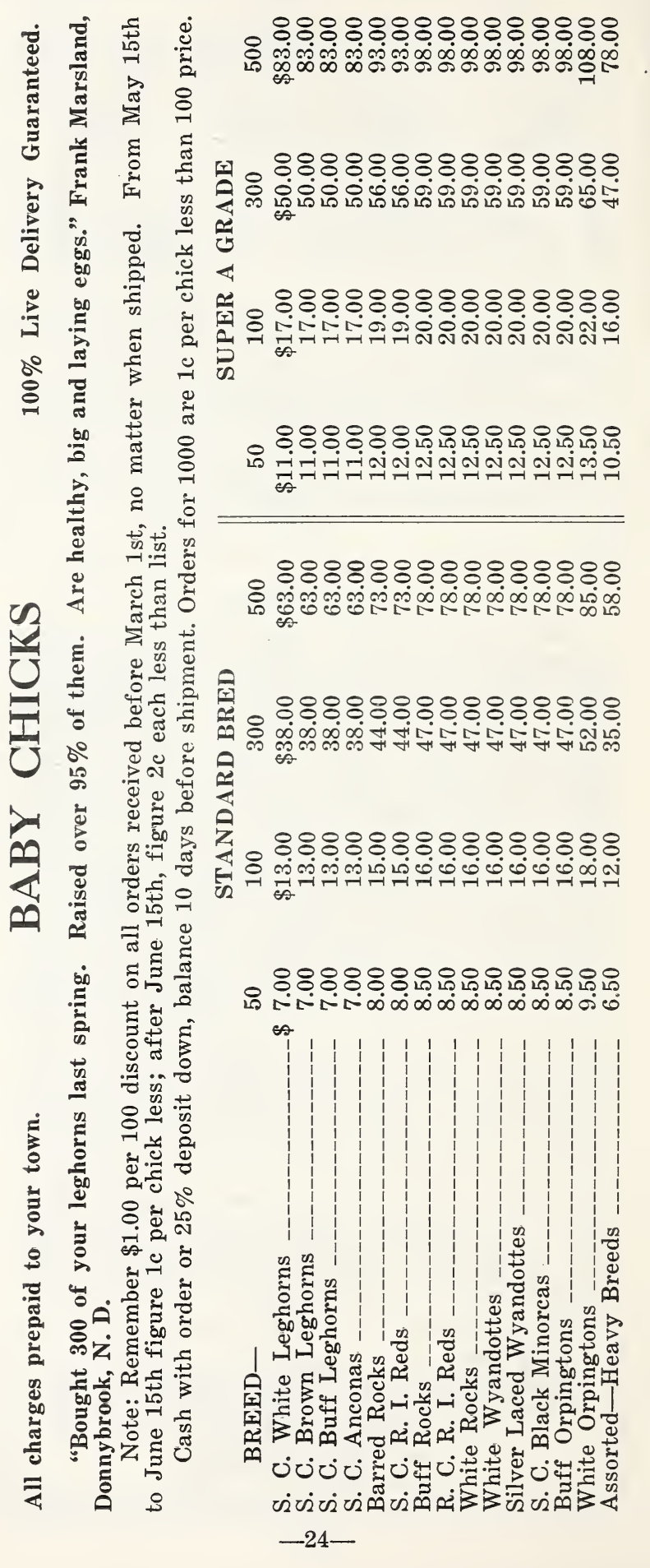




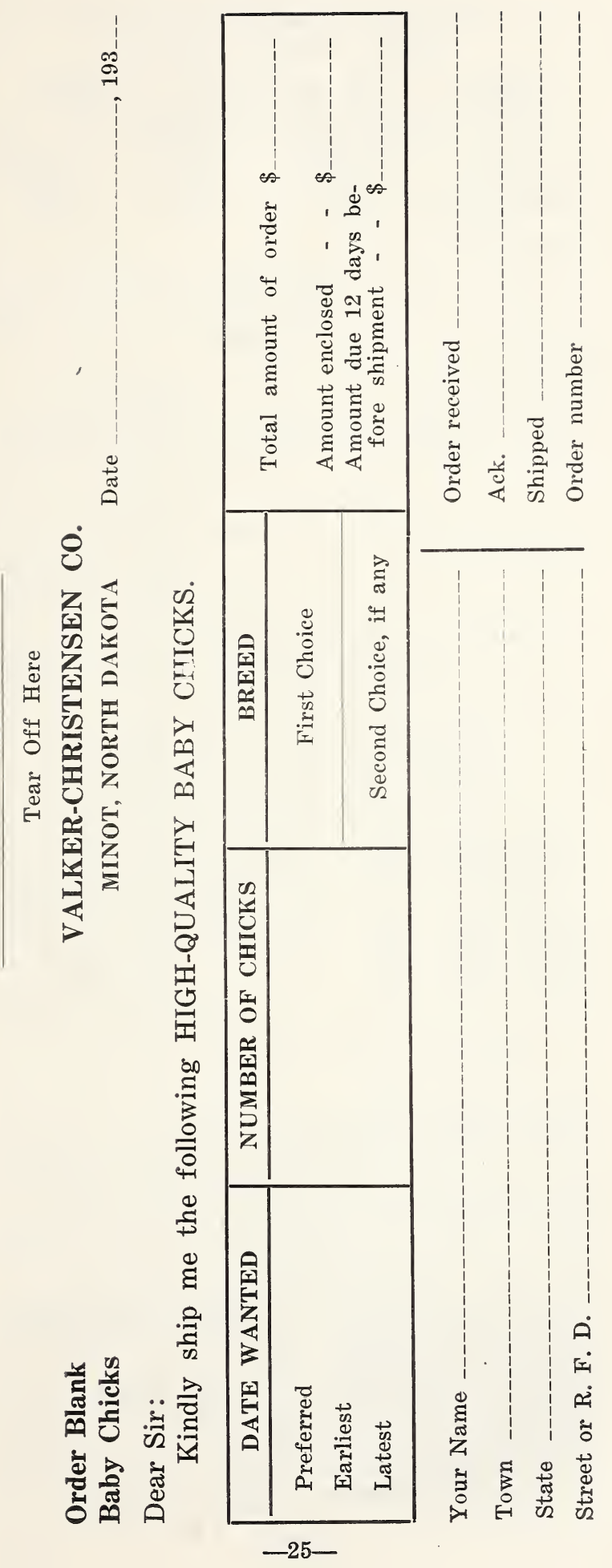




\section{VALIKER-CHRISTENSEN CO.}

MINOT, NORTH DAKOTA

Seeds - Feeds - Potatoes - Chicks

Poultry and Bee Supplies

Ship To

Date 19

Name

Post Office

R. F. D.

Box

County

State

Shipping Point

Agent There?

SHIP_Freight____-_ Express__-_- Parcel Post

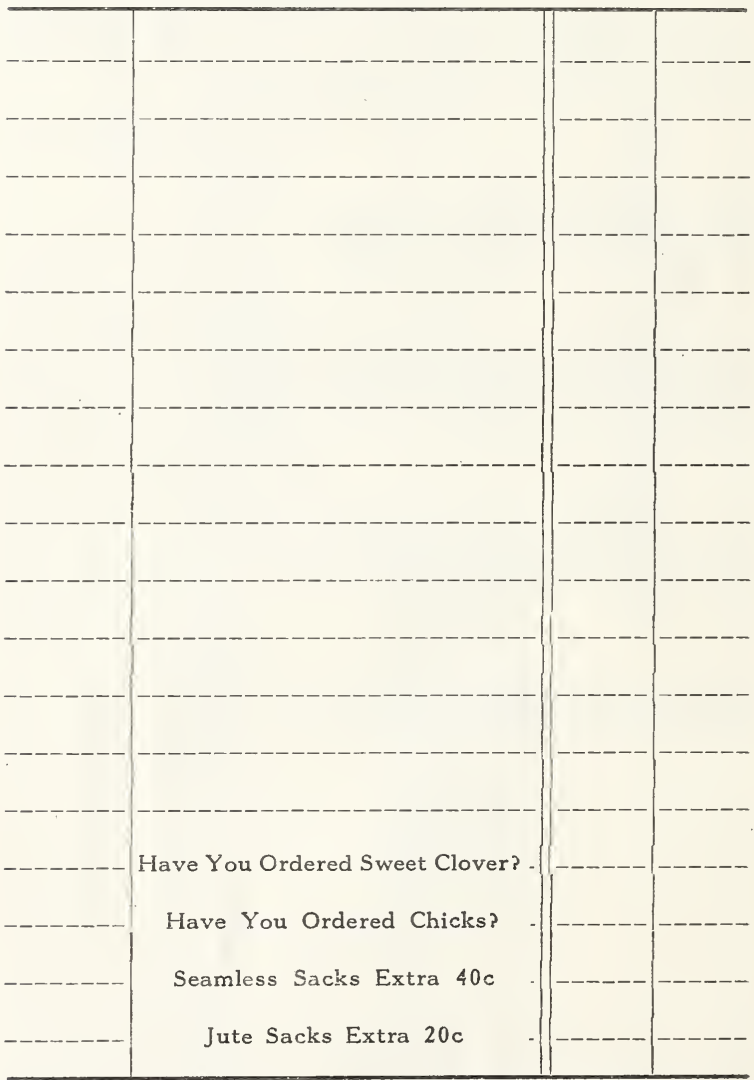

Ship above subject to terms and conditions on inside front cover of your catalogue. Valker-Christensen Co. gives no warranty, express or implied, as to description, quality, productiveness, or any other matter of any seeds they send out, and will not be in any way responsible for the crop.

AMOUNT ENCLOSED

Cash - - \$

P.O. Exp. order $\$$

Draft - - $\$$

Stamps - - \$

Total - - \$ 

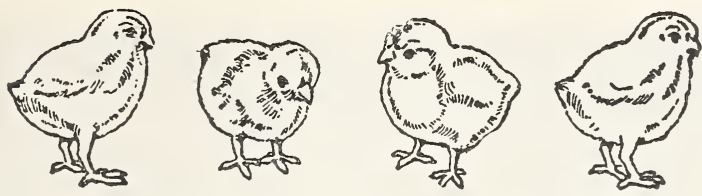

I am interested in purchasing

Baby chicks for delivery about

I prefer $\begin{cases}\text { Specify } & 1 . \\ \text { Choice } & 2 . \\ \text { of Breeds } & 3 .\end{cases}$

I am expecting to raise

laying hens and turkies the coming season.

Just fill out coupon and insert in our self addressed envelope. No stamps necessary.

\section{"EXTRA QUALITY" CHICKS}

\section{EXTRA-HIGH QUALITY STOCK}

$\begin{array}{lccc} & 50 & 100 & 300 \\ \text { Partridge Plymouth Rocks } & \$ 10.50 & \$ 20.00 & \$ 58.00 \\ \text { Golden, Buff, Partridge or Co- } & & & \\ \text { lumbian Wyandottes } & \mathbf{1 0 . 5 0} & \mathbf{2 0 . 0 0} & \mathbf{5 8 . 0 0} \\ \text { Rose Comb Black Minorcas }--- & \mathbf{1 0 . 5 0} & \mathbf{2 0 . 0 0} & \mathbf{5 8 . 0 0} \\ \text { White Minorcas --_--------- } \mathbf{1 0 . 5 0} & \mathbf{2 0 . 0 0} & \mathbf{5 8 . 0 0} \\ \text { Light Brahmas - } & \mathbf{1 0 . 5 0} & \mathbf{2 0 . 0 0} & \mathbf{5 8 . 0 0} \\ \text { Jersey Black Giants --------- } & \mathbf{1 3 . 0 0} & \mathbf{2 5 . 0 0} & \mathbf{7 2 . 0 0}\end{array}$

\section{LIMITED NUMBER RARE VARIETIES}

$25 \quad 50 \quad 100$

Ferris Strain S.C.W. Leghorns_\$ $5.50 \quad \$ 10.50 \quad \$ 20.00$

Tompkins Strain R. or S.C. Reds $\quad 5.50 \quad 10.50 \quad 20.00$

Thompson Strain Barred Rocks

or Fished White Rocks ___- $\quad 5.50 \quad 10.50 \quad 20.00$

Regal Dorcas White Wyandottes $\quad \begin{array}{llll}\mathbf{5} .50 & \mathbf{1 0 . 5 0} & \mathbf{2 0 . 0 0}\end{array}$

Byers Strain Buff Orpingtons_ $5.50 \quad 10.50 \quad 20.00$

We do not try to make a fortune or even a reasonable profit on each chick sale. We believe that our chicks will prove so far above any that you have ever had before, that you will become a booster for us in your vicinity. You will then buy our other products and in that way we profit, thru the sale of more lines at lower profits. Our policy of smaller profits per sale has resulted in our volume business. Try us on chicks and let us prove their worth. 
I am interested in planting of Corn in 1930. I will probably want field seeds in the following amounts and varieties:

bu.

bu. potatoes

lbs.

lbs.

I would like to have seed shipped about

Send me details of your offer to accept $25 \%$ of present purchase price and protect me against advancing market, I to pay balance upon arrival of seeds. Use enclosed addressed envelope. No stamps necessary to order from Valker-Christensen Co.

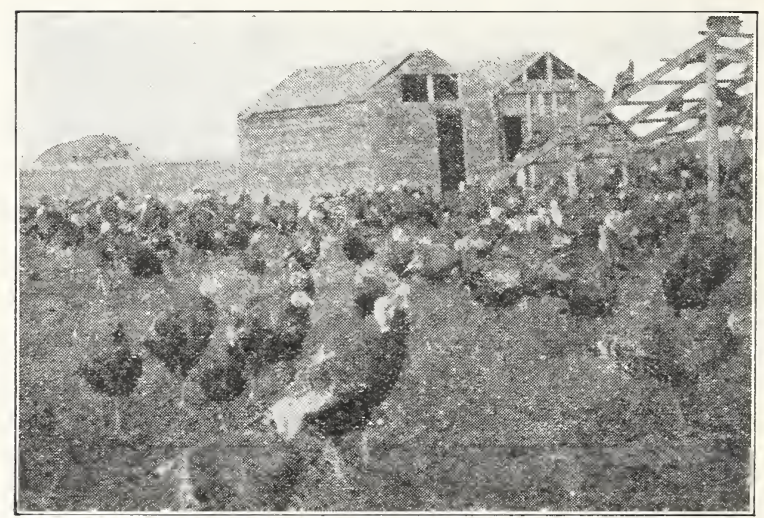

View of Mrs. Middaugh's 600 Turkeys.

Mrs. R. B. Middaugh

Chicago, Ill. Nov. 8, 1929

Lansford, N. Dak.

Dear Madam:

Enclose sale for your turkeys. We wired you. Wanted you to know that we know good poultry when we see it and that we got you the price. Your sale is for four cents above the highest quotations here today.

$$
\begin{array}{r}
\text { Yours very truly, } \\
\text { Dauber Bros. }
\end{array}
$$

Valker-Christensen Co.

Minot, N. Dak.

We thought you might be interested in this letter as our turkeys were raised on your feed. Yours truly,

Mr. \& Mrs. R. B. Middaugh, 


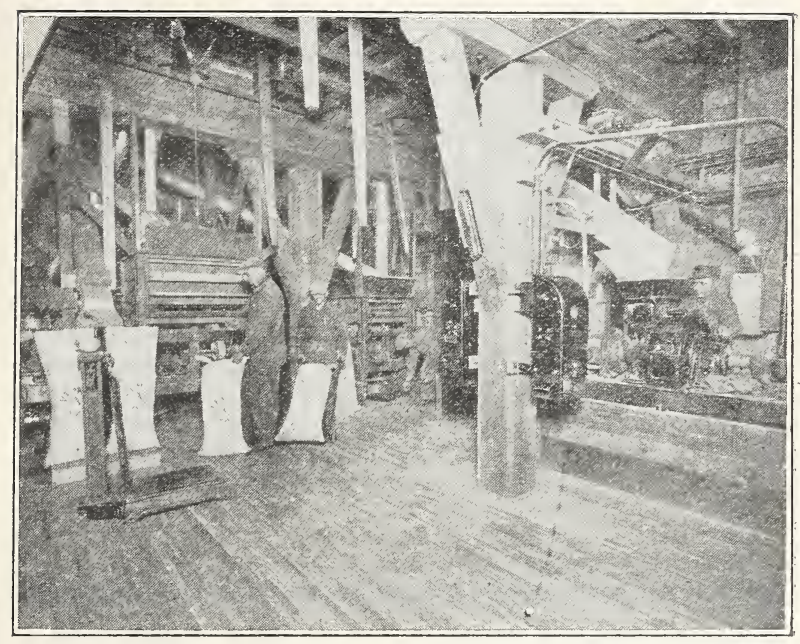

A few of our cleaning mills and equipment for properly cleaning and handling our seeds and feeds. In addition this view does not show our feed mixing and molasses treating equipment, nor the scarifier and special grass seed cleaners. Hard wood floors save sacks and metal lined bins eliminate mixing varieties. Notice how clean everything is kept. In excess of $\$ 15,000$ of machinery and equipment, means better seeds and feeds to this region.

\section{FEED DEPARTMENT}

Prices subject to change without notice.

We are now the largest manufacturers of prepared feeds in western North Dakota. Every sack of our feed complies with the state feed laws and have been recommended by various experiment stations. Realizing that in order to build up a successful Feed Department, quality comes first, we are putting into our feeds only the very best ingredients.

Remember Dakota Leader Feeds are all made in Minot, at the source from which all basic ingredients such as bran, middlings, oil meal, etc. originate. This enables us to save freight to the Twin Cities and back on our feeds, which accounts for our selling our feeds so low in comparison with eastern manufacturers. Our feeds are equal to the very best and most expensive feed made any place yet sell for less than the lowest grade shipped in feeds because of our big advantage over eastern houses. Why build up eastern houses when we furnish a market here at home for your grains and save you freight both ways on your finished products.

Our egg mash sales this last fall doubled over the previous year. We expect to more than double our chick feed sales this spring. We had any num- 
ber of folks come in last spring to our retail store and even when we offered the highest priced shipped in brand of chick feed at the same price as ours, the customer took ours, because, as they said, "We have tried yours, and it cannot be beat". Why experiment when hundreds of our friends have already done that and have standardized on Dakota Leader Feeds for profit and satisfaction.

\section{DAKOTA LEADER POULTRY FEEDS}

A laying hen can be likened to a manufacturing plant. You will get eggs only if you put in all the various ingredients that are necessary for egg production. This means that the hen must have equal parts of egg mash, and scratch feed, containing corn, oyster shells, grits, meat scraps and plenty of water.

On the average farm half of the hens could be culled from the flock without losing more than 3 to 5 per cent of your egg production. Cull your flocks and give the balance of your chickens a fair chance by feeding them right feeds and put your flock on a highly profitable basis.

Dakota Leader Egg Mash-19\% Protein-Our egg mash has no superior on the market today, re-

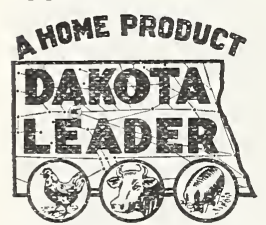
gardless of price. This is our leader and contains the very best ingredients such as meat meal, bone meal, oil meal, dried buttermilk, skimmilk, MinrolProtin, the new wonder feed. Every trial order results in commendation on the results from feeding Dakota Leader Egg Mash. Priced low, but superior value.

Per 100 lbs. $\$ 3.00$

Dakota Leader Growing Mash-The ideal feed for growing chicks after having reached 6 weeks of age. Contains the right proportions of bone and body building ingredients, but costs less than the starter mash.

$50 \mathrm{lbs}$. $\$ 1.75$

$100 \mathrm{lbs}$.

Dakota Leader Hen Scratch Feed-Mature birds need equal amounts of scratch feed and egg mash to secure maximum results. The Missouri Experiment Station found an increase of over $300 \%$ in egg production from the feeding of half of each over the feeding of straight mash or straight scratch feed. Contains cracked corn, wheat, barley, kaffir, buckwheat, and sunflower in correct proportion. $100 \mathrm{lbs}$.

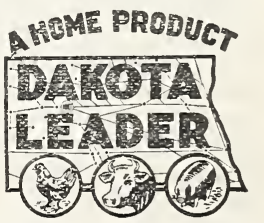
$\$ 2.60$

We are as close to you as your nearest postoffice. Simply make up your order, check it over and give it to your mailman. No postage needed. We do the rest. 
Dakota Leader Chick Starter Mash-17\% protein-Regardless of how good the chicks are, the HOEE PRODU care and feed given, make good

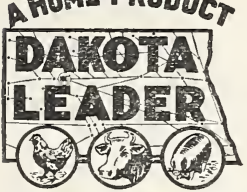
chicks better. We urge the placing before your chicks of our tried and proven Starter Mash when chicks are 24 hours or more old. Feed for $15 \mathrm{~min}$ utes at a time from 5 to 7 times daily, increasing as they grow. Regardless of what you have previously fed and what you have paid, we feel confident that our location enables us to give you not only better feed but for the money, our feed cannot be equaled. Discriminating poultry women all over attest to Dakota Leader supremacy and we have used no high pressure salesmanship to sell our feed. It has sold on its merit.

Variety, cleanliness, and balanced make-up insure satisfaction to chick and owner. Contains such ingredients as ground corn, oat meal, meat meal, bone meal, fish meal, oil meal, minerals, alfalfa meal, yeast, cod liver oil, powdered whole milk and buttermilk, etc.

$100 \mathrm{lbs}$.

$50 \mathrm{lbs}$.

$25 \mathrm{lbs}$.

Dakota Leader Turkey Starter-Turkey raising is becoming a bigger factor yearly in this region. Much depends on the right feed to start the turks out on. Our feed has given the young turks several weeks start over those not fed our feed. Think of what this means for Thanksgiving market.

$25 \mathrm{lbs}$.

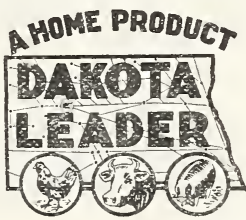

$50 \mathrm{lbs}$

$100 \mathrm{lbs}$.

Dakota Leader Chick Feed-A fine scratch feed for chicks which can be fed after first three weeks Per 100 lbs. $\$ 3.50$

Per 50 lbs. 1.90

Per 25 lbs. - 1.00

Dakota Leader Granular Chick Feed-We have had so many calls for a granular feed that can be

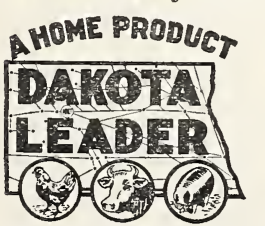
fed to chicks, that we are now manufacturing a feed that requires no mash or scratch feed, the Granular Chick Feed in itself being a scratch feed, to be fed in the straw, making the chick work for its feed. Contains granular meat, wheat, kaffir, milo, charcoal, millet, bone, clover seed, buttermilk, oatmeal, dry cod liver oil and grit. Once tried, always used.

$25 \mathrm{lbs}$. 
Dakota Leader Turkey Mash-21\% Protein. To those who have used our turkey mash, we need say

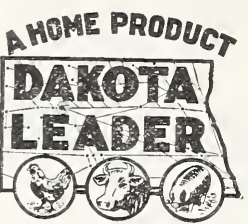
nothing. It is made higher in protein than mash for chickens. Leading turkey experts approve of our mash and we have discriminating raisers who attest to its efficiency. Mrs. R. B. Middaugh of Lansford had 600 of the finest turkeys in North Dakota. Her toms in October ranged from 22 to 26 lbs. each. With equal care and plenty of Dakota Leader feed you can do likewise. Composed of Meat Meal, Bran, middlings, salt, pulverized oats and ground corn, etc. Write for ton prices.

$100 \mathrm{lbs}$.

Dakota Leader Cracked Corn-Uniform. Made from very finest corn obtainable.

Per $100 \mathrm{lbs}$.

Shellmaker-A limestone product which contains $99 \%$ digestible calcium. Many people prefer this to oyster shell. Experiments show chickens are keen for it. Our sales already exceed two carloads this fall and winter. Try a few sacks.

$100 \mathrm{lbs}$.

Oyster Shell-Our oyster shell is the genuine shell and not a clam shell. Our stocks secured from Gulf states. Hens increase egg production and all poultry need limestone in some form.

Per $100 \mathrm{lbs}$.

Meat Scraps-Poultry men are gradually awakening to the importance of this high protein feed. Our meal is of best quality, clean and no mash is complete without its liberal use to poultry.

Per $100 \mathrm{lbs}$.

Dakota Leader Dairy Feed 34\%-Due to high price of oil meal and absence of silos on most farms, we have been manufacturing a feed containing the same protein as oil meal, but has more variety and succulence. A molasses feed that increases milk flow and builds up the cow's body. No waste materials. Leading dairymen feeding it. Mix 1-3 this feed with 2-3 home grown grains to get the necessary $17 \%$ protein for your cows.

Per $100 \mathrm{lbs}$.

Glenburn, N. Dak.

Dakota Leader Egg Mash sure makes our chickens lay. The pullets are only 6 months old but we get many more eggs than our neighbors, whose chicks are several months older, some of them feeding some of the high priced shipped in mashes. Your egg mash is low in price and also does what it is supposed to do-produce eggs.

\section{Yours truly,}

Geo. Hagan.

All prices f. o. b. Minot, drayage free 
Dakota Leader Calf Meal-So many farmers

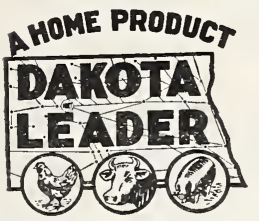

$25 \mathrm{lbs}$.

$100 \mathrm{lbs}$. have use for their milk and yet want to raise their calves at as low a cost as possible. Our Calf Meal answers this need fully and satisfactorily. Made of Blood Meal, Red Dog Flour, Oil Meal, Hominy Meal, Corn Meal, Dried Skimmilk and Salt.

Alfalfa Meal. Our meal is from green alfalfa hay ground medium fine and is excellent for use in mixing home mashes, or for winter use where green feed is not available.

$100 \mathrm{lbs}$.

$50 \mathrm{lbs}$.

Charcoal-Ford. We are distributors of Ford extra quality charcoal in hen and chick size. Uniform in qutlity and size.

$50 \mathrm{lbs}$.

$100 \mathrm{lbs}$.

Cottonseed Meal-43\%. Dairymen have been underestimating the value of this high protein feed in milking cows. No quicker results can be obtained than by the use of equal parts of oil meal and cottonseed meal when added to the regular home grown ground oats and barley. $100 \mathrm{lbs}$. each oil meal and cottonseed meal added to $600 \mathrm{lbs}$. ground feed make ideal cow feed.

$100 \mathrm{lbs}$.

\section{Semi-Solid Buttermills}

Semi-Solid Buttermilk is creamy buttermilk condensed to the point of maximum feeding and medicinal value. Its health giving qualities and resistance to disease has been proven to thousands who have fed it under all conditions and who are now making it a regular portion of their daily hog and poultry rations. A remedy and preventive for scours in hogs. Is ideal for pigs suffering from Necrotic Enteritis. Dilute one part Semi-Solid Buttermilk to seven parts water for poultry. For chicks feed undiluted or dilute one part milk to four parts water. For hogs dilute one part to 40 parts water.

Barrels

$\$ 4.25$ per cwt. Half Barrels 4.75 per cwt.

Kegs $\mathbf{5 . 2 5}$ per cwt. 5 gal. pail 4.15 per pail

Semi-Solid with $20 \%$ Codliver Oil added:

Barrels $\$ 5.20$ per cwt. Half Barrels 5.70 per cwt. Kegs 6.20 per cwt. 5 gal. pail 4.75 per pail 
Gentlemen:

Mohall, N. Dak. January 8, 1930

A short time ago we purchased through the Mohall Shipping Assoc. 500 lbs. Oil Meal and $500 \mathrm{lbs}$. Cottonseed Meal and must say we are well pleased with results. Cows give much more milk and we feed less hay and grain. We milk 20 cows and supply about $90 \%$ of all milk sold in Mohall. We had to have some way to get results and we got it. Thought this might be of some interest to you.

Yours truly,

J. A. Southam.

Beet Pulp-Unexcelled for dairy cows for succulent feed. Our stock fresh.

$100 \mathrm{lbs}$. $\$ 2.75$

\section{MISCELLANEOUS FEEDS}

In addition to the above feeds we carry a complete line of feeds for all kinds of live stock:

Oil Meal, per 100 lbs.

Cottonseed Meal, per $100 \mathrm{lbs}$. -

Feed Corn, per 100 lbs.

Oyster Shells, per 100 lbs.

Meat Scraps, per 100 lbs.

Bone Meal, per $100 \mathrm{lbs}$.

Rolled Oats, per 100 lbs.

Dried Buttermilk, per 100 lbs. -

Dried Buttermilk, per 50 lbs.

Grits, per 100 lbs.

Corn Gluten Feed, per 100 lbs.

Feed Oats, per 100 lbs.

Ground Oats, per 100 lbs.

Ground Barley and Oats, per $100 \mathrm{lbs}$. -

Feed Speltz, per 100 lbs.

Feed Buckwheat, per 100 lbs.

\section{HAY.}

Due to dry season in 1929 hay is scarce in Montana and North Dakota. We are located in the heart of a good hay producing section and altho crop was not plentiful, we shall be glad to fill orders for carlots while the supply lasts.

We can furnish No. 1 Upland, No. 2 Upland, Blue Joint and Alfalfa at this time. We suggest pooling orders for one town with your neighbors if your dealer does not want to order for you and handle it. We are selling hay close to help out the people in need of forage crops this year. A car of hay varies from 10 to 20 tons, so state what size car you prefer when writing for prices.

\section{STANDARD OF PERFECTION}

The official authority for Fanciers, Breeders and Judges. A complete description of every recognized breed and variety of Fowls, Water Fowls and Turkeys, with Standard requirements as to shape and color markings in every section.

Price, Postpaid: Cloth_-_-_ 2.50 ; Leather $\$ 3.50$ 


\section{A L K E R - C H R IS T E N S E N C O M P A N Y}

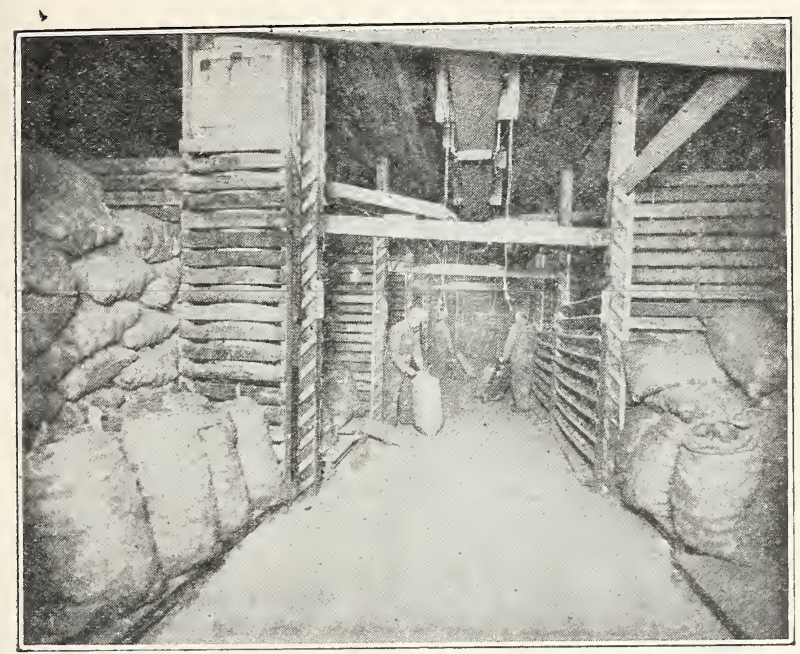

Inside of our modern, mammoth potato house, which was filled with better than 15,000 bushels of potatoes this season. We stored in bulk this year to increase the capacity. Every bushel is double sorted when it comes in and again sorted when we sack and ship out. Temperatures are kept at $34^{\circ}$ to $36^{\circ}$ at all times, fans being used to keep temperature even. Ventilation provided around the bottom, sides and thru the center of each bin. All this means better potatoes for the buyer who uses our potatoes.

\section{SEED POTATOES}

All potatoes put up in 2-bu. sacks extra at 12c.

We have taken over the large potato warehouse in Minot and are in a position to buy or sell all kinds of potatoes in the fall. We have one of the best equipped and most modern potato warehouses in North Dakota and invite you to inspect our place whenever in the city. We also have sacks, twine, insecticides, etc.

Cobblers, Prince Edward, Registered SeedCobblers are early, round, sound and our stock one of the few certified fields in North Dakota in 1929. We are confident that the state cannot produce a finer lot of seed than we have to offer this spring. Prof. Bolley, N. D. plant wizard recommends this variety as the earliest white potato and believes $\mathrm{N}$. D. should increase the growing of this strain. This potato is exceptionally mealy, fine flavor and heavy yielder. Book order now on our down payment plan. Per bu. $10 \mathrm{bu}$. or more -

Uncertified Cobblers, per bu. $10 \mathrm{bu}$. or more 
Triumph Potatoes-Certified and Registered. Western North Dakota is fast coming to the front in the growing of certified Triumphs. With our clean and disease-free lands our growers will profit by getting into the certified seed potato game, rather than raise common table stock in competition with eastern points with their lower freight rates to consumption centers. Our seed is North Dakota grown from rogued fields and certified by State Agricultural College. Each bag tagged by state. 2 bu. to sack.

Per bu. $\$ 2.75$

Triumphs-We have a supply of Triumphs raised from Certified seed, but grower failed to take care of the inspection. Had he done so, this field would no doubt have made certified seed.

Per bu.

$10 \mathrm{bu}$. or more

$\$ 2.25$

Early Ohios-A very fine table potato and well liked for baking purposes by restaurants. Good yielder and in good demand in the fall. Our stock was put in early.

Per bu.

$10 \mathrm{bu}$. or more

$\$ 2.25$

We also have table stock, all U. S. Ones, sorted and graded that we can quote special prices on, based on market. Write for prices, baglot or carlot.

The potato market this year is so uncertain and if 1930 is anything like 1919 and other years when U. S. crop was not as short as 1929 , we are going to witness an acute shortage of supplies and unheard of prices. We therefore urge you to get your supplies booked while present prices prevail. As long as our stocks hold out, we will hold prices down but if we have to replace our stocks, will necessarily have to go up with the market keeping in mind that this section has to ship in from the east.

Take no chances on potatoes. Order now.

Potato Bags-2 bu. $7 \frac{1}{2}$ oz. per 100 $\$ 12.00$

Used once bags, 2-bu. per 100 $\$ 9.50$

We have bags, twine, insecticides, paris green, lead arsenate, etc. Send us your orders.

Our $34 \%$ Dairy Feed sells for less because we mix our own feeds here, thus saving freight and double profit so necessary with other feeds when handled by many hands. Buy direct from us and be assured of low feed costs.

\section{NO POSTAGE REQUIRED}

Realizing the inconvenience to so many of our customers in securing stamps and having them on hand when ordering seeds and supplies, we have taken advantage of a new postal regulation permitting payment of postage at destination, thus saving our customers bother and making it easier for you to order our merchandise. 


\section{POULTRY SUPPLIES}

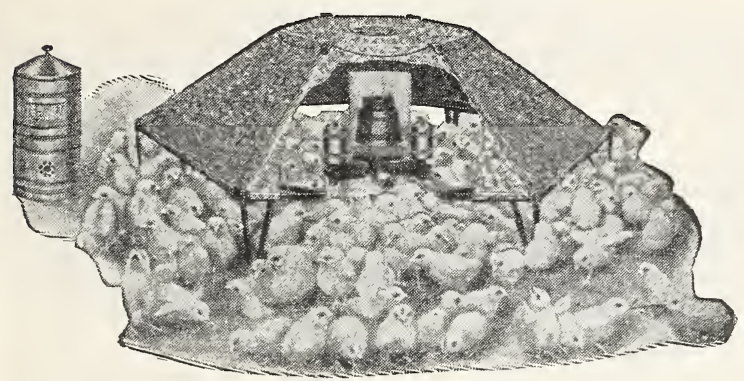

Sol-Hot 1929 Model Brooder-The Sol-Hot is the only brooder on the market that has a different size burner for each size canopy. It costs more to build but is more economical for you. It is just as important to put a larger heater under a 1000-chick canopy as it is to put a larger stove in a ten room house than goes into a four room house. Our experience with Sol-Hot enables us to recommend this brooder very highly. One customer wrote in that he rever turned his stove off all spring.

Sol-Hot has a twin float control so that regardless of whether your floor is crooked or whether it is on a slant or not your oil level is uniform. No wicks, ashes, dirt, dust, smoke or soot. Uniform heat. Made of heavy materials, oil container large size, flexible wire, no funnel necessary to refill.

24-inch canopy, 100 chicks

34-inch canopy, 250 to 300 chicks

44-inch canopy, 500 chicks _-_-_-_-_-_-_ $\mathbf{2 0 . 5 0}$

54-inch canopy, 1000 chicks _-_-_-_-_-_-_ 22.50

Giant Sol-Hot-54-inch canopy, 1000 chicks, price large stove _-_-_-_-_-_-_-_-_-_ $\mathbf{2 4 . 5 0}$

New Modern Giant Special-64-inch canopy, 1200 chicks, price

We can furnish Sol Hot heaters without canopy as follows:

Size 24 in. Standard

Size 34 in. Standard -

Size 44 in. Standard _-_________- 14.50

Size 54 in. Standard __________- 15.75

Size 54 in. Giant

Size 64 in. Giant

If you want parts for your Sol Hot write for same.

Sol-Hot Automatic Thermostat Oil ControlFor use where operator cannot watch too closely, proves an oil and time saver. Price ________ $\$ 3.75$

Write us for special literature and descriptive booklet on Sol-Hot lines.

Electric Brooder-We can also supply the $\mathrm{Ma}$ komb electric brooder for small flocks; 24 in. diameter, complete with $10 \mathrm{ft}$. cord and screw plug.

Price each

Write us for our special catalogs, specifying whether you want the Sol-Hot or Makomb equipment. 


\section{QUEEN INCUBATORS}

We have had nothing but praise from our customers on this line of incubators, which is so well known and liked by all users. Made in the following sizes:

Queen, 85 egg size, each $\$ 27.50$

Queen, 135 egg size, each 39.50

Queen, 180 egg size, each 44.50

Queen, 275 egg size, each 57.75

Queen, 400 egg size, each 76.50

Queen, 600 egg size, each 97.50

Style "K" Queen Incubator

70 egg size, each

130 egg size, each $\$ 18.50$

220 egg size, each 36.75

Thermometers-Genuine Tycos brooder thermometer with black metal scale $4 \frac{1}{2}$ in. long. Scale range $20^{\circ}$ to $120^{\circ}$.

No. 127 , each $70 \mathrm{c}$

Vertical Feeder-Large capacity, suitable for large or small flocks. Magazine adjustable up or down, bottom cone shaped, cannot clog. Chicks unable to foul feed. Smooth holes, accurately formed. No. 1192, 10 pts., 30 holes, each $\$ 1.40$ No. 1793, 18 pts., 30 holes, each $\$ 1.85$

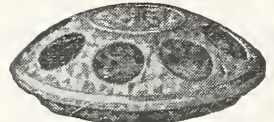

Moe's Baby Chick Feeder No. 111, 8 holes, each _-_-_10c No. 112, 12 holes, each $20 \mathrm{c}$ clean.

Moe's Feeding Troughs-Sliding top, easy to No. 127, 10 inch length $20 \mathrm{c}$ No. 128, 20 inch length $35 \mathrm{c}$

Moe's Drinking FountainFor chicks. Can be attached to any glass jar.

Price, each $10 c$

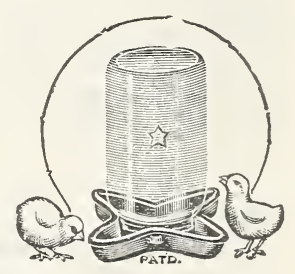

Jan. 28, 1930.

Dear Sir:

The chicks we got from you sure are fine. Send me your catalog. I wanted to get some rye grass seed.

Yours trulv, Chas. Papendick, Ray, N. D. 


\section{POULTRY EQUIPMENT}

Moe's Improved Top Drinking Fountain-Filled from the top by removing cover. By filling the fountain once a day, poultry are assured of a day's supply of water.

No. 1, 1 gal. size

No. 2, 2 gal. size

No. 4, 4 gal. size 3.00

Moe's Large Capacity Feeder-Has 32 feeder holes, sliding top, easy to fill and clean, 10 quart capacity. Fastest selling feeder on market today.

No. 1140, 21 inch length $\$ 1.20$

No. 1141, 54 feeder holes $\$ 1.75$

Moe's Wall, Shell and Grit Boxes-Made with 2, 3 or 4 compartments, enabling use of different feed in each compartment.

No. 145, 2 compartments $\$ .50$

No. 19, 3 compartments 1.00

No. 190, 4 compartments

\section{HUDSON POULTRY EQUIPMENT}

Chick Feed Trough-V shaped bottom and flanged edge prevent waste of feed. Wire guard top adjustable. Suitable for day old to 6 week old chicks. Easily cleaned.

20 inch (OF20) each 35c 30 inch (OF30) $45 \mathrm{c}$

Capacity Chick Feeder-Inexpensive, for chick feeding. Inverted V shape hopper, prevents clogging, covered top.

30 inch (CF30) each

$90 \mathrm{c}$

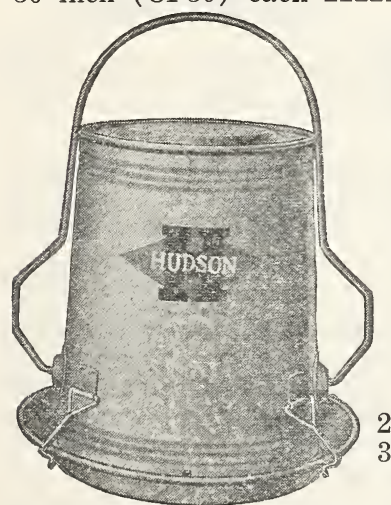

Chick Fountain Handy fill, made of heavy galvanized iron in 2 pieces. Top is made two way swinging bail, permitting pail to be carried filled or not. Smooth, rolled edge especially designed for small chicks. Easy to fill. Easy to clean. ow in price.

2 gal. CW 2

3 gal. CW 3

Leg Bands - Celluloid spiral bands, made for chicks, chickens and turkeys; all colors. Specify breed and kind of poultry when ordering.

1 doz. bands $s_{--} 20 \mathrm{c} 50$ bands $_{-} 60 \mathrm{c}$ 25 bands _.___._35e 100 bands_._85e

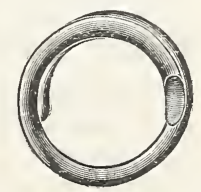

Thermostat Wafers-double for Queen incubators, medium size, each

Buttermilk Feeder-Gallon crocks, with base suitable for milk and buttermilk feeding. No danger from acid such as metal feeders expose poultry to. Reasonably priced, each $85 \mathrm{c}$ 
Hudson Sprayer-New 110-G Perfection Galvanized tank, high pressure, best quality. Provides easy and economical means for applying white wash, cold water paint, stains, etc. Practical in garden, orchard and buildings. 4 gallon capacity. One in carton.

Each $\$ 7.50$

Hudson Insulated Waterer-Improved type, has many new and original features. Operates on fireless cooker principle. Fill in the morning with hot water. No clamps, valves or corks to adjust. No upkeep. Keeps water cool in summer. Gives your poultry more uniform temperature water so they will drink more. Sturdily built, two parts. More poultry can drink at one time.

3 gal. size, PW3

6 gal. size PW6 5.75

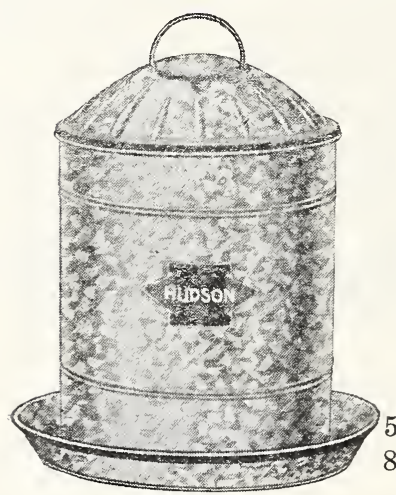

Mammoth Chick Waterer-Large capacity chick fountain, double wall, keeping water cool in summer. Altho not insulated, it will retard freezing in winter because of double wall. Vacuum principle. Automatic valve prevents over running when being filled.

Wall Mash Feeder-Ideal where there is limited floor space. $3 \mathrm{ft}$. long, 8 in. wide and 5 in. deep. Hinged grill swings open for filling and cleaning. No. 230.

Each

Mammoth Chick Feeder-The latest and best feeder put on the market regardless of price. Inverted $\mathrm{V}$ shape hopper, optional feed arrangement for individual chick or raising out of the way. Top raises up for cleaning and refilling. Positively sells on sight. Biggest dollar value on market.

24 inch $\mathrm{CF} 24 \mathrm{~W}$

36 inch CF36W

48 inch $\mathrm{CF} 48 \mathrm{~W}$ 2.40

Mammoth Chick Feeder-Same as CF24W except canopy projection for bad weather.

24 inch $\$ 1.75$

36 inch

48 inch 3.00

Lawn Rakes-For removal of dandelions and raking and top dressing the lawn.

No. 16

No. 20 
Garden Seeder-Hudson. Complete with drill and hill seeder, rakes, plows, cultivators, one and two wheel cultivator. Sturdily built of best materials.

Each $\$ 17.75$

Junior Sprayer-Galvanized tank. $2 \frac{1}{2}$ gallons capacity. Made for folks who want smaller capacity but still need high pressure air sprayer.

Each

Chemical Sprayer-Handles all solutions made up from oil base. No rubber hose to give way under chemicals or acids. $1 \frac{1}{2}$ gal. capacity. Tested under $60 \mathrm{lb}$. pressure.

Each $\$ 5.25$

Misty Sprayer-Universally used around house, barn, poultry house, garden. Strong, simple and neat. One full quart capacity. Heavy tin construction. Well made.

Each $45 \mathrm{c}$

\section{HOILAND WILD OATS SEPARATOR}

The famous Hoiland Separator is the only machine that will thoroughly remove wild oats from

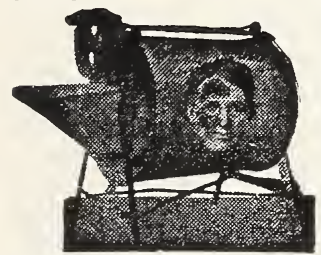
tame oats, wheat and other grains. Consists of heavy revolving drum lined with flannel. The wild oats stick to the flannel and when drum comes to top wild oats drop into receptacle and are carried away. The single size 18 to 25 bushel capacity per hour $\$ 35.00$

Double size 25 to $40 \mathrm{bu}$. per hour $\$ 50.00$

\section{B. CLIPPER SEED CLEANER}

The Clipper $1 \mathrm{~B}$ is a small size seed and grain cleaner similar to the cleaners found in all seed houses. They are the most effective seed cleaners on the market. Simple, sturdy and rigid. Nothing complicated. Operated by hand or power. $4 \mathrm{ft} .8 \mathrm{in}$. long, 2 ft. 2 in. wide, 3 ft. 8 in. high, 12 screens $19 \times 29$ in. Cleans small seed $10 \mathrm{bu}$. Coarse grains $20 \mathrm{bu}$. per hr.

Price each f. o. b. Minot $\$ 39.00$

\section{B. CLIPPER CLEANER}

Same as 1 B, except $4 \mathrm{ft} .8 \mathrm{in}$. long, $2 \mathrm{ft}, 8 \mathrm{in}$. wide, $3 \mathrm{ft} .8 \mathrm{in}$. high, 12 screens $25 \mathrm{in}$. wide, $22 \frac{1}{4}$ in. long. Cleans 15 bu. small seed, 25 bu. coarse grain per hour.

Price each f. o. b. Minot $\$ 45.00$

Easy Cultivator-The outstanding garden hand cultivator on the market, breaks up hard surface as well as pulverizes it. Ten times as fast as hand hoeing. Kills all weeds under the surface. Easy to operate, efficient, sturdy construction, low in price. No garden complete without an Easy.

8 in., each

10 in., each $\$ 9.75$

Cyclone Seeder-Just the thing for seeding small fields of sweet clover, alfalfa and other grass seeds. Easily adjusted to any rate of seeding. 


\section{POULTRY \& STOCK REMEDIES \& TONICS}

Black Leaf 40-Contains $40 \%$ Nicotine. Kills poultry lice. Paint it on roosts. Fumes are slowly released and penetrate feathers, killing lice. Works while they roost. Makes an excellent dip for sheep, cattle and hogs, controlling ticks, lice and scab. A very good drench for removing sheep stomach worms. Unexcelled as a plant spray for soft bodied sucking insects. Highly concentrated and inexpensive to use.

$1 \mathrm{oz}$.

$1 / 2 \mathrm{lb}$. $35 \mathrm{c}$

2 lbs.

$10 \mathrm{lbs}$.

Choloree-A sure remedy and prevention for chicken cholera and the common diseases of turkeys and chicks, including White Diarrhoea in baby chicks. Guaranteed to give full satisfaction or money refunded. Concentrate form-will make quart of medicine. Highly recommended.

Price per bottle, makes 1 qt. medicine

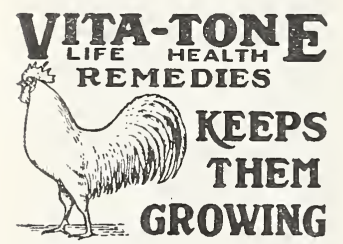

Vita-Tone Poultry Tablets for treatment of white diarrhoea, cholera, roup, for chicks, turkeys and all poultry. Also acts as a preventive and tonic.

Bottle, 50 tablets _... $50 \mathrm{c}$ 100 tablets

$\$ 1.00$

Vigoro-A specially prepared plant food for Lawns, Flowers, Shrubbery, Trees. Promotes maximum growth, beauty and production. A complete food for all growing things, producing a vigorous root system and early growth. Cost is about 10c to $20 \mathrm{c}$ per $100 \mathrm{sq}$. feet.

100 lbs.

$50 \mathrm{lbs}$.

25 lbs.

$5 \mathrm{lbs}$.

Wool Bags-Standard size $7 \frac{1}{2} \mathrm{ft}$. long, unturned, made of best of materials. Standard weight wool bag, 64 oz. hemmed top.

Each $75 \mathrm{c}$

10 bags $\$ 7.25$

100 bags 70.00

Write for prices on No. 2 bags and large quantities of new wool sacks.

Rat Killer-Not a poison-Kills only rats and mice; safe to use anywhere. Harmless to human beings, livestock, poultry or pets. A very effective rat destroyer.

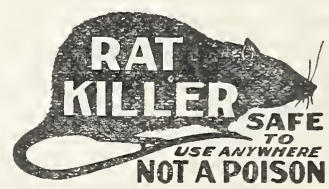

Price 2 oz. 100-150 baitings

Large 8 oz. farm size 


\section{POULTRY REMEDIES}

Coliverol-Cod liver oil in powdered form. Many claim for Coliverol that it retains vitamines and feed value better and is easier to mix with ground feed.

Per lb. $-25 \mathrm{c}$

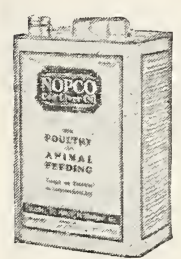

NOPCO-Cod Liver Oil. For poultry and animal feeding, a triple bulktested oil; guaranteed pure and potent, contains vitamine $\mathrm{A}$; prevents rickets in poultry.

1 qt. tin

$1 / 2$ gal. tin 1.75

1 gal.

5 gal.

14.00

Miller White Diarrhoea Remedy-Tablets for prevention and cure of white diarrhoea and other bowel trouble.

Box of 10 tablets 50 c; 6 boxes, $\$ 2.50 ; 12$ boxes, $\$ 5.00$

Russell's Worm R-Mix with feed for expelling worms and other intestinal parasites from poultry. Worms greatly reduce vitality. Worm $\mathrm{R}$ guaranteed to remove worms and use thereafter 2 to 3 times a year will insure against worms.

Price per pkg.

$65 \mathrm{c}$

Large Size

$\$ 1.00$

Russell's Worm X for expelling worms. A tablet dropped into throat of fowl very effective.

Per bottle $\$ 1.00$

Russell's Kurum-A very good liquid preventive and remedy for white diarrhoea, sorehead, roup, cholera, coccidiosos and other germ diseases of poultry. Put Kurum into drinking water.

8 oz. bottle $65 c$

16-oz. $\$ 1.00$

1 gallon $\$ 5.00$

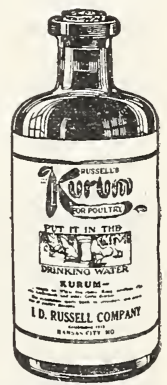

Russell's Revenge Lice Destroyer-Disinfectant, Germicide, Deodorizer. Kills head lice, body lice and other parasites on poultry and stock. Also flees on dogs. Will not shake off. Made to do the work. Satisfaction guaranteed.

$11 / 21 b$. can

Large size

Antrol-Ant Syrup-For controlling sweet eating ants. Attracts ants quickly. Fed to Queens and other members, which poisons entire colony. Set of 4 jars and 1 pt. syrup, $\$ 1.60$; Empty jars $15 \mathrm{c}$ each, 1 pt. syrup, $\$ 1.00$. 


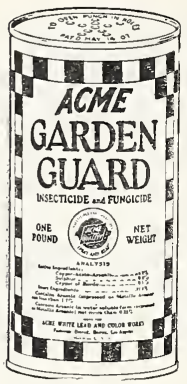

INSECTICIDES

Sure Noxem

Garden Guard

For cabbage, cauliflower, cucumber, squash, currant, gooseberry, melon vines, tomato, and other vegetable plants. Sifter can tops.

Per pkg. $30 \mathrm{e}$
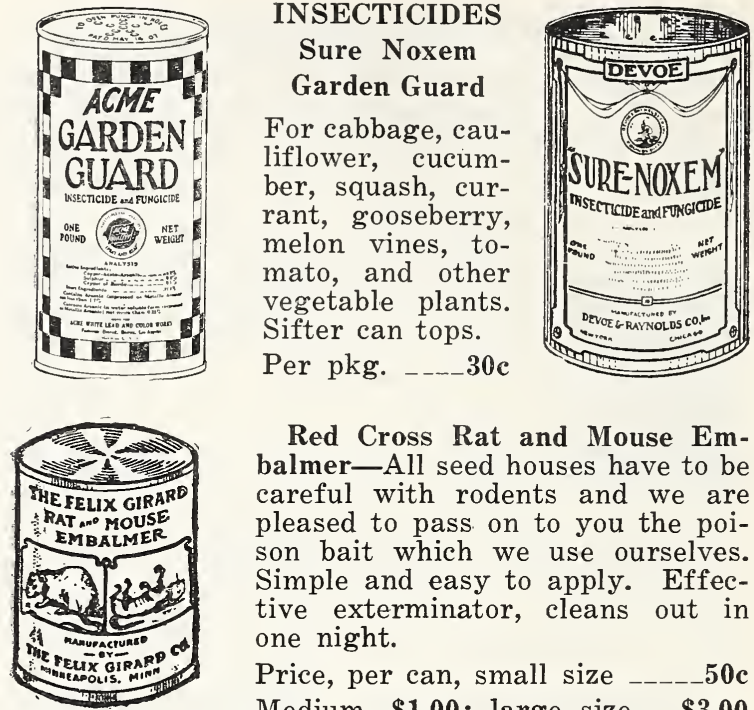

Red Cross Rat and Mouse Embalmer-All seed houses have to be careful with rodents and we are pleased to pass on to you the poison bait which we use ourselves. Simple and easy to apply. Effective exterminator, cleans out in one night.

Price, per can, small size Medium, $\$ 1.00$; large size _- $\$ 3.00$

Acme Bordeaux Mixture-Prevents large losses caused by blight, rot, mildew, scab, anthracnose and certain other fungous diseases.

Per lb. $40 \mathrm{c}$

Acme Bait-M-An effective insecticide bait which will throw a ring of protection around shrubs, flowers and plants in garden and lawn.

Per lb. $50 \mathrm{c}$

Acme All Round Spray-New 3-Way Spray. Save your roses, plants, vegetables, shrubs and trees from the ravages of chewing insects, sucking insects, blight and fungi.

$1 / 4$ lb. tins each $45 \mathrm{c}$

$1 \mathrm{lb}$. tins each

Corona Coppercarb-Used in treating seed wheat for stinking smut. Only dry powder method that we have that saves mixing with water. Highly recommended by experiment stations and wheat disease authorities. Also increases yield of grain. Has no ill effect on grain such as formalin. You can treat your grain now and leave lay until spring, befor seeding. Economical, safe, easy and quick. No bother with water. One pound treats 8 bushels. Comes in 5-lb. packages by express or freight.

Per pound

\section{Gentlemen:}

I received the 25 Buff Orpington Baby

Chicks. They came through fine.

Yours very truly,

Mervin Peterson,

Big Sandy, Mont. 
4 Row Field Potato Sprayer-No. 27. Complete with pump for attaching to rear of wagon $--\$ \mathbf{\$ 2 7 . 0 0}$

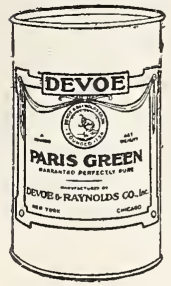

Paris Green. Devoe \& Raynolds Brand.

$1 \mathrm{lb}$.

$45 c$

5 lb. packages

$14 \mathrm{lb}$. kits, the most popular size $\$ \mathbf{5 . 6 0}$ $100 \mathrm{lb}$. drums

Ceresan-A single dust disinfectant to treat your wheat, oats, barley and other cereals. The latest discovery for control of loose and covered smut of oats, stem smut of rye, stinking smut of wheat, loose and covered smut of barley. Is harmless to seed, easy to apply and one dust for ali diseases. $1 \mathrm{lb}$. treats $4 \mathrm{bu}$.
8 oz. tin $\$ .50$
1 lb. tin
25 lb. pail
$\$ 12.50$
5 lb. tin
.75
100 lb. drun.
49.00
$300 \mathrm{lb}$. drum
144.00

\section{DAKO'TA LEADER FROST PROOF CABBAGE PLANTS}

Plants that produce cabbage a month earlier than home grown plants. Our stocks secured from Atlantic Coast where climatic conditions are right for production of hardy cabbage plants that do not need to be hardened off before planting.

Following varieties available: Early Jersey Wakefield, Charleston Large Type Wakefield, Early Flat Dutch and Copenhagen Market.

Prices-Cabbage and Onion Plants, parcel post prepaid.

\section{DAKOTA LEADER FROST PROOF ONION PLANTS}

These have been giving satisfaction for some years. Grown in winter in Texas and ready for planting here when frost leaves ground. Onions will be earlier than when planted from sets or seed. We offer Yellow Bermuda and Crystal White Wax, only.

Prices-Cabbage and Onion Plants, parcel post prepaid.

100 to 400 plants, per 100,60 ; 500 plants, $\$ 1.70$; 1000 or more, per $1000, \$ 3.25$. By express 1000 to 4000 plants at $\$ 2.25$ per $1000 ; 5000$ or more plants per 1000 at $\$ 1.75$. Packed 5000 to case.

\section{NOTICE}

A new sweet corn has been developed at the Agricultural College even earlier than Sunshine, and it will go under the name of Golden Gem. Supply is limited and none for sale this year. If you wish to reserve a quantity for 1931 , write now and be assured of some of the earliest yellow sweet corn developed. 


\section{GARDEN SEEDS AND FLOWERS}

$1 / 4$-lb. $1 \mathrm{lb} .5 \mathrm{lb}$.

Beans, Golden Wax, Stringless__-_ $\$ .15 \$ .50 \$ 2.25$

$\begin{array}{lll}.15 & .50 & 2.25\end{array}$

Great Northern -

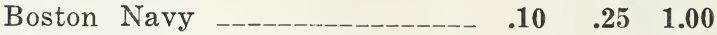

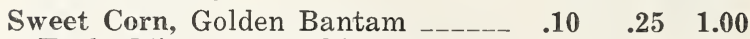

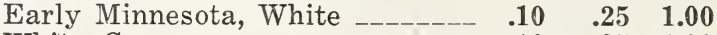

White Cory _-

Golden Sunshine, developed in

North Dakota 10 days earlier

than Golden Bantam, larger

size and very sweet

$\begin{array}{lll}.15 & .45 & 1.90\end{array}$

Peas, Early, not dwarf, First and best

Early Alaska, Mature quickly _---

Gradus or Prosperity

$\begin{array}{lll}.10 & .30 & 1.25\end{array}$

$.10 \quad .30 \quad 1.25$

$.10 \quad .30 \quad 1.25$

Peas, Dwarf, American Wonder _-_ $\quad \begin{array}{llll}\mathbf{1 0} & \mathbf{. 3 0} & \mathbf{1 . 2 5}\end{array}$

Premium Gem _-_-_-_-_-_-_-_ $\quad \mathbf{. 1 0} \quad \mathbf{. 3 0} \quad \mathbf{1 . 2 5}$

Peas, Main Crop. Everbearing $\quad \begin{array}{llll}.10 & .30 & 1.25\end{array}$

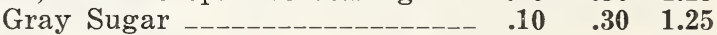

Beets, Eclipse

Oz. 1/4 lb. $1 \mathrm{lb}$.

Detroit Red Dark

$\$ .10 \$ .25 \$ .70$

Improved Crosby

$\begin{array}{lll}.10 & .25 & .70\end{array}$

Swiss Chard

$.25 \quad .70$

Sugar Beet, Klein W.

$\begin{array}{lll}.10 & .25 & .70 \\ .10 & .25 & .70\end{array}$

Stock Beet, Mammoth Long Red

$\begin{array}{lll}.10 & .20 & .55\end{array}$

Golden Tankard

$\begin{array}{lll}.10 & .20 & .50 \\ .10 & .20 & .50\end{array}$

Cabbage. Early Jersey Wakefield _-

Copenhagen Market

$.75 \quad 1.90$

Late Flat Dutch

$\begin{array}{lll}.25 & .75 & 1.90\end{array}$

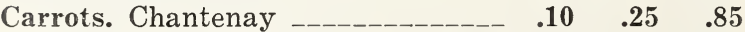

Danvers Half Long _-___-__-_ $\quad .10 \quad .25 \quad .85$

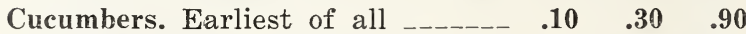

Imperial Long Green

White Spine

Chicago Pickling -

Lettuce. Big Boston _____ $\quad \begin{array}{rrr}15 & .40 & 1.10\end{array}$

Grand Rapids

Early Curled Simpson

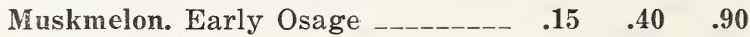

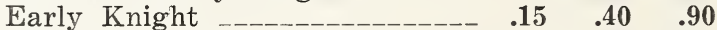

Watermelon. Harris Early _-_-_-_ $\quad .10 \quad .25 \quad .75$

Red Citron _-

Parsley. Moss Curled _-__-_-_-_-_ $\quad \mathbf{1 0} \quad .25$

Guernsey _-_-_-_-_-_-_-_-_-_- $\quad .10$

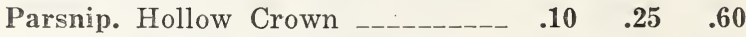

Onion Seed. Red Weathersfield _-- $\quad .25 \quad .60 \quad 1.75$

Prizetaker _._-_-_-_-_-_-_-_-_

Silverskin _-_-_-_-_-_-_-_-_-

Yellow Danvers

Pumpkin. Field -------_-------

Sugar Pie

Radish. French Breakfast _..---

The Saxa -

Early White Turnip _-_-_---

Early Scarlet Turnip 


\begin{tabular}{|c|c|c|c|}
\hline & Oz. & $1 / 4 \mathrm{lb}$. & $1 \mathrm{lb}$. \\
\hline Rutabaga. American Purple Top & .10 & .20 & .50 \\
\hline Squash. Golden Hubbard & .10 & .25 & .90 \\
\hline Improved Hubbard & .10 & .25 & .90 \\
\hline Crookneck & .10 & .25 & .90 \\
\hline Spinach. Savoy & .10 & .25 & .60 \\
\hline Tomatoes. Earliana & .25 & .90 & \\
\hline Early Jewel & .25 & .90 & \\
\hline John Baer & .25 & .90 & \\
\hline Yellow Pear & .25 & .90 & \\
\hline Turnip. White Egg & .10 & .25 & .60 \\
\hline Purple Strap Leaf & .10 & .25 & .60 \\
\hline Kale & .10 & .25 & \\
\hline Salsify & .10 & .25 & \\
\hline Kohl Rabi & .10 & .25 & \\
\hline & Pk. & $\mathrm{Oz}$ & \\
\hline $\begin{array}{l}\text { Cauliflower. Early Snowball } \\
\text { Danish Dry Weather }\end{array}$ & & $\begin{array}{l}1.90 \\
1.90\end{array}$ & \\
\hline FLOWER SEEDS & & & \\
\hline $\begin{array}{l}\text { Sweet Peas, Spencer Mixed }----- \\
\text { Nasturtium, tall }\end{array}$ & & .25 & .75 \\
\hline Nasturtium, dwarf & & 20. & .60 \\
\hline
\end{tabular}

ONION SETS

Red, White, Yellow, per quart, 25c; peck, \$1.25.

\section{VEGETABLE PLANTS}

Direct to you from the largest greenhouse in the state. Plants are all hardy, early varieties, tried and tested for North Dakota. We recommend potted plants as they not only are larger but will produce several weeks earlier than flat grown. Specify choice, early or late.

Notice-Plants are highly perishable and we recommend express shipment. Pool orders with your neighbors to get benefit of volume purchase and reduce express charges.

\begin{tabular}{|c|c|c|c|}
\hline & Doz. & 50 & 100 \\
\hline Cabbage, Early & $\$ .25$ & $\$ .75$ & $\$ 1.25$ \\
\hline Cabbage, Late & .25 & .75 & 1.25 \\
\hline Cauliflower & .35 & 1.25 & 2.50 \\
\hline Celery & .35 & 1.25 & 2.25 \\
\hline Tomato, transplanted & .50 & 1.75 & 3.25 \\
\hline Tomato, Pot Grown $2 \frac{1}{2}$ in. & 1.00 & 3.50 & 6.50 \\
\hline Tomato, Pot Grown 4 in. & 2.00 & 6.00 & 11.00 \\
\hline nd Cherry, Pot Grow & 1.00 & 3.50 & 6.50 \\
\hline Ground Cherry, Transplanted & .50 & 1.75 & 3.25 \\
\hline$-\ldots------------------$ & 1.00 & 3.50 & 6.50 \\
\hline bage Pla & $0 \cap 0$ & & \\
\hline
\end{tabular}

Cabbage Plants, per $1000 \ldots$

On parcel post add $10 \mathrm{c}$ per doz. to above prices.

\section{RADIO PROGRAMS}

Valker-Christensen Co., desirous of rendering greater service to our growing list of customers, is taking the lead in broadcasting programs and entertainment over the following radio stations: KLPM, Minot, every Monday evening $7: 15$ to $7: 45$, and every noon; KGCX, Wolf Point, Mont., every morning at 10 o'clock; KFYR, Bismarck, 7:30 to 9:30 A. M. 


\section{INDEX}

Fage

Page

A

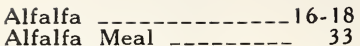

Alsike Clover --.--- 22

Amber Cane -

Antrol

Ant Syrup _.. 43

\section{B}

Baby Chicks _._._._- 23.27

Barley _... 13

Bee Supplies - 22

Beet Pulp 34

Binder Twine - 22

Black Leaf 40 -.--- 42

Blue Grass ---

Bone Meal _-_.-- 34

Bordeaux Mixture --.- 44

$\begin{array}{lr}\text { Brome Grass - } & 9 \\ \text { Brooders } & \end{array}$

$\begin{array}{lr}\text { Brooders } & 37 \\ \text { Buckwheat } & \end{array}$

C

Cabbage Plants _-_-_-_45.47

Calf Meal _.________- 33

Cane

Ceresan

Charcoal _. 33

Chicks _-_-_-_-23

Chick Feed - 31

Chick Starter Mash _-_ 31

Choloree _._-_._-_-_ 42

Clipper Cleaner -..-- 41

Coal Brooder _._._._- 37

Cod Liver Oil _._. 43

Coppercarb _-

Corn, Seed _-_-_-_ 2-6

Corn Gluten Feed _-_- 34

Cossack Alfalfa _..-- 18

Cottonseed Meal _-_-_ 33

Cracked Corn _-_--- 32

Crested Wheat Crass _- 9

Cultivator

Cyclone Seeder

\section{D-E}

Dairy Feed

Diarrhoea Remedy D. E. Rape Dried Buttermilk _.--_

Feeders 38.39

Feed Buckwheat

Feed Corn _._. 34

Feed Oats

Feed Speltz _._._-_- 34

Field Peas

Flax

Flower Seeds _- 47

$\begin{array}{ll}\text { Fodder Corn } & 6 \\ \text { Fountains } & \end{array}$

\section{G}

Garden Guard

Garden Seeder

------ 44

Garden Seeds ------- 41

Gluten Feed

Gopher Poison - 22

Granular Chick Feed 31

Grimm Alfalfa

Grits

Ground Barley------- 34

Ground Cherry Plants - 47

Ground Oats

Growing Mash
H

$\begin{array}{ll}\text { Hay } & \\ \text { Hen Scratch Feed } & \end{array}$

I-J-K-L

lncubators _._._. 38

Inoculate _.

lnsecticides _-_._-_-_ 44

Kaffir Corn _..._... 7

Kurum _._._._-_ 43

Lice Destroyer _- 43

\section{M}

Marquis, Registered _- 12

Mash Feeder _._-_-- 40

Meat Scraps - 32

Millet _-_-_-_-_-10-12

Miscellaneous Feeds -- 34

\section{N-O}

Nitragin -.--_-_-_-_- 19

Oats

Oil Meal

Onion Plants

Onion Sets

Order Blank _...-..- 26

Oyster Shell -..- 32

\section{$\mathbf{P}$}

Paris Green _._-_-_-_ 45

Pepper Plants _-_-_-_ 47

Plants _._-_-_-_-_ 47

Potato Sprayer

Potatoes

Poultry Remedies _--- $42-43$

Poultry Supplies _-_-- 38-40

\section{$\mathbf{R}$}

Rape Seed _-_-_-_-_ 8

Rat Poison - 42

Red Top 10

Rolled Oats - 34

Rye
Rye Grass

\section{S}

Scratch Feed

Seed Corn - 2 -6

Seed Grains -

Seed Potatoes - - - 35-36

Semi-Solid Buttermilk_- 33

Shellmaker

Speltz 13

Spray - 44

Sprayer - 41

Standard of Perfection 34

Sudan Grass _..._.- 7

Sunflower Seed ----- 74

Sure-Noxem -------- 44

Sweet Clover $-------19-22$
Sweet Fodder

T

Timothy _._._._. 10

Thermometer 38

Tomato Plants _-_-_- 47

Turkey Mash _._-_-_ 32

Turkey Starter _._-_- 31

Twine _...- 22

\section{V-W}

Vegetable Plants _-_-_ 47

Vigoro 42

Vita-Tone -

Waterer

Wheat Grass -

Wheat

White Clover

Wild Oats Separator -- 41

Wool Bags 42

Worm Remedy _-_-_-- 43

Worm X 


\section{GENERAL INFORMATION}

\section{Average Amount of Garden Seed Or Number of Plants for One Acre}

Asparagus plants, $4 \times 11 / 2 \mathrm{ft}$. 7790

Beans, Bush, in drills, $2 \frac{1}{2} \mathrm{ft}$. $11 / 2 \mathrm{bu}$.

Beans, Pole, Lima, $4 \times 4 \mathrm{ft}$. $15 \mathrm{qts}$.

Beets and Mangels, in drills, $21 / 2 \mathrm{ft}$. $6 \mathrm{lbs}$.

Cabbage in outdoor beds for transplanting -Cabbage sown in frames

$8 \mathrm{oz}$.

$4 \mathrm{oz}$.

Carrot in drills, $21 / 2 \mathrm{ft}$.

4 lbs.

Celery Seed

$8 \mathrm{oz}$.

Celery plants, $4 \mathrm{x}^{1 / 2} \mathrm{ft}$. 20,000

Corn, Sweet

$8 \mathrm{qts}$.

Cucumbers in hills, $3 \times 4 \mathrm{ft}$.

$2 \mathrm{lbs}$.

Lettuce in rows, $2 \frac{1}{2} \mathrm{ft}$.

$3 \mathrm{lbs}$.

Melon, Musk, in hills, $4 \times 4 \mathrm{ft}$.

$3 \mathrm{lbs}$.

Melon, Water, in hills, $8 \times 8 \mathrm{ft}$.

$4 \mathrm{lbs}$.

Onions in rows for sets

Onions in rows to make large bulbs

$60 \mathrm{lbs}$.

Parsnips in drills, $21 / 2 \mathrm{ft}$. -

Pumpkin in hills, $8 \times 8 \mathrm{ft}$.

$3 \mathrm{lbs}$.

Parsley in drills, $2 \mathrm{ft}$.

$5 \mathrm{lbs}$.

Peas in drills, short varieties

Peas in drills, tall varieties

Radish, in drills, 2 ft.

$2 \mathrm{bu}$.

Spinach, broadcast

Squash, Running, in hills, $8 \times 8 \mathrm{ft}$.

Turnip, in drills, $2 \mathrm{ft}$.

Turnip, broadcast

Tomato, seęd in hills, $4 \times 4 \mathrm{ft}$.

1 to $1 \frac{1}{6} \mathrm{bu}$.

$6 \mathrm{lbs}$.

$30 \mathrm{lbs}$.

3 lbs.

$2 \mathrm{lbs}$.

$3 \mathrm{lbs}$.

3 oz.

\section{Table of Weights Per Bushel and Rates of Seeding}

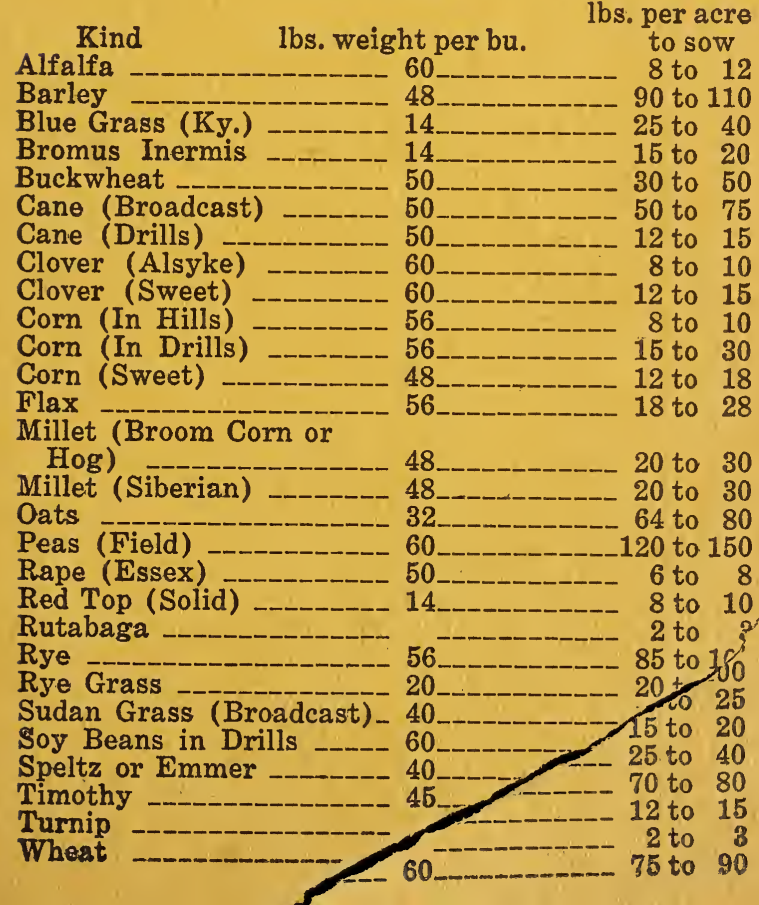

\section{SEED \\ LEGUMES \\ 1930}

Soil conditions in 1929 were a $g$ a in ideal for the seeding of sweet clover, alfalfa and othor grasses. With hay short in most localities this year, we urge seeding down of plenty of above seeds for hay.

Have you ordered enough seed corn and feed crops? Feed crops can always be fed to advantage. Hogs are wonderful property and corn and alfalfa will bring big returns when fed.

Buy Baby Chicks from us and get your chicks from accredited flocks. Cost only a trifle more but worth it. Poor chicks are more expensive in the long run. Order Now.

Always plant grass seeds shallow on firm seed bed. 

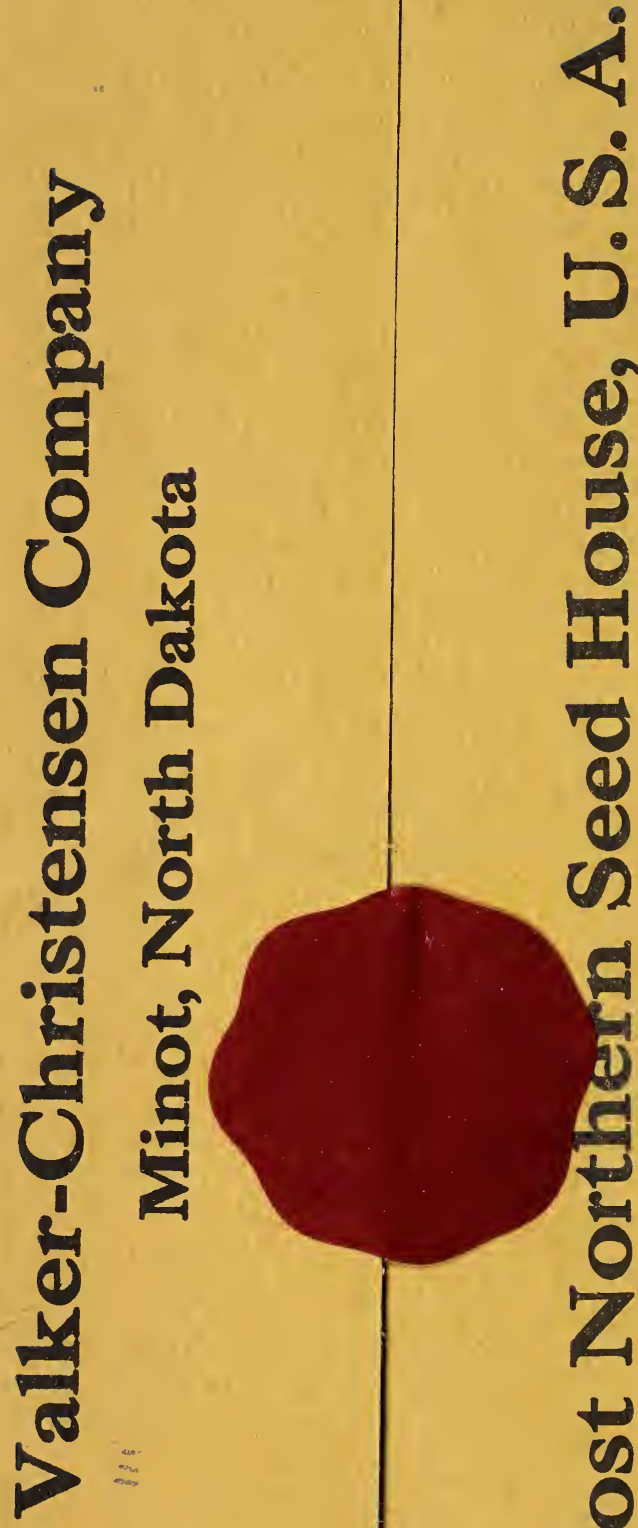

(1)

(2)

บ

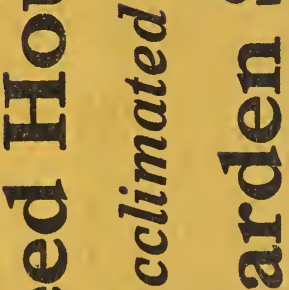

d)

๘

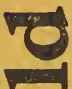

(1)

$\rightarrow$

I

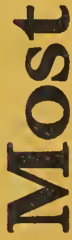

